\title{
Concept of education: Confluence of definition criteria, temporary formative orientation and common activity as core content of its meaning
}

\section{El concepto de educación:}

La confluencia de criterios de definición, orientación formativa

\section{temporal y actividad común como nucleo de contenido de su significado}

José Manuel TOURIÑÁN LÓPEZ

Catedrático de Teoría de la Educación

Universidad de Santiago de Compostela.

Facultad de Ciencias de la Educación.

Departamento de Pedagogía y Didáctica.

Campus Vida s/n. 15782. Santiago de Compostela.

Webs particulares: http://dondestalaeducacion.com/

https://www.youtube.com/channel/UCzbNAzwFApNMViix5_HDzOw

Researcher ID: http://www.researcherid.com/rid/L-1032-2014

Orcid: http://orcid.org/0000-0002-7553-4483

Premio Internacional Educa-Redipe 2019 (Trayectoria profesional).

Resolución de 18 de mayo de 2019 


\section{ABSTRACT}

In this work, the purpose is to establish the need to go beyond the nominal definition of the concept of education and justify the existence of distinctive traits of the real definition of the term 'education' in character and sense inherent in its meaning, which must be taken into account at all times and places, whenever we carry out pedagogical intervention.

It is about forming criteria on meaning of 'education' and importance of Pedagogy in the construction of education fields. Knowledge of education makes it possible to build fields of education over cultural areas, transforming information into knowledge and knowledge into education. And this requires executing pedagogical function with competence, establishing an educational relationship in which common activity is the working tool.

\section{KEY WORDS}

Pedagogy as a discipline; Concept of Education; Complexity of Education; Temporary Formative Orientation; Pedagogical Function; Educational Relationship; Activity Principle.

\section{INTRODUCTION}

It is a common observation that the true knowledge of things is only attained through the experience of its frequent use, since it allows us to get an idea of them and reach its meaning or understanding by means of a personal assimilation. This generally occurs in all kind of matters, but it is especially useful for the spheres of knowledge. That is why the understanding of the meaning of a term is a late and reflexive result more than an entirely a priori task without previous experience. I am writing this work from that conviction.

In general, every definition can be verified in a double way: as a nominal definition or as a real definition, depending on whether it focuses respectively on the word or name with which we designate a thing, or on the traits and particular characters of the thing which is designated. The nominal definition offers the signification of a word, whilst the real definition expresses the distinctive and singular characters of the thing that we try to define.

It is usual, before elucidating the traits which are identified in the real definition, to consider the signification of the word with which we name it. The study of the word has been specified in the definition in two ways: attending to its origin and to its synonymy. The nominal definition has two modalities: etymological definition and synonymic definition. In the first case, the method which we use to express the signification of a term is resorting to its origin; in the second case, we reach its meaning by looking for its explanation by means of other more common voices and with a similar signification.

In this work, the purpose is to establish the need to go beyond the nominal definition of the concept of education and justify the existence of distinctive traits of the real definition of the term 'education' in character and sense inherent in its meaning, which must be taken into account at all times and places, whenever we carry out pedagogical intervention.

The development of this work can be summarised in the following theses:

- Nominal definition is necessary, but not sufficient

- Real definition requires attending to character traits and meaning linked to the object 'education' and the educational act

- $\quad$ Concept of education is integrated into the temporary formative orientation in each territory by means of the curricular architecture

- Knowing, teaching and educating do not mean the same thing 
- Pedagogical function generates intervention from the common activity

- Educational relationship allows us to go from knowledge to action by accomplishing values-feelings concordance in each pedagogical intervention

- And, precisely because of this, we can conclude that the concept of 'education' is understandable as a confluence of meaning and temporary formative orientation in each intervention, counting on internal and external common activity.

Ultimately, it is about forming criteria on meaning of 'education' and importance of Pedagogy in the construction of education fields. Knowledge of education makes it possible to build fields of education over cultural areas, transforming information into knowledge and knowledge into education. And this requires executing pedagogical function with competence, establishing an educational relationship in which common activity, internal and external, is the working tool.

\section{THE STARTING POINT TOWARDS} THE REAL DEFINITION OF EDUCATION IS IN THE COMMON USE OF THE TERM AND IN THE ACTIVITIES WHICH ARE CARRIED OUT

According to the principle of meaning, apart from discerning and defining, the real definition demands to understand, that is to say, it demands to know in a full sense: 1) to show the logical need for some characters or constitutive traits, 2) to reason theoretically and practically about its principles and 3 ) to measure the impression of reality which they transmit us. Therefore, it makes sense to affirm that the undefinition of meaning is a constant source of bad comprehension and of erroneous considerations. When the meaning is ambiguous, we interpret other people, other things and ourselves badly: we distort and misrepresent because of ambiguity (Dewey, 1998, p. 140).

From the perspective of the nominal definition and the finality related to the activities, 'educating' is basically to acquire a set of behaviours which qualify educatees to choose, to engage, to decide, to perform their personal life project and to construct themselves by using the axiological experience in order to give an answer to the demands that may arise in each situation according to the opportunities. It is a question of making educatees acquire knowledge, attitudes and skills-abilities-habits which qualify them to choose, to engage, to decide and to perform their projects by giving an answer to the demands that arise in each situation according to the opportunities, from every internal common activity: think, feel affectively, want, choosedo (operate), decide-act (project) and create (build by symbolising), and from every external common activity (game, work, study, profession, investigation and relationship) (Touriñán, 2014).

From the perspective of the nominal definition and the activity, it is affirmed that the educational activity is "educational" because its finality is to educate and it adapts meaning to the criteria of common use of the term, like any other entity which is defined nominally and is comprehensible. The criteria of common use of the term and the criteria related to the activities allow us to discern and to relate the definition to the finality: the concept of education is demarcated whenever the criteria of common use of the term are fulfilled and the aim of educating is preserved. This is necessary, but it is not enough if we want to make a real definition.

\subsection{The Concept of Education Is Nominally Related to Criteria of Common Use of the Term}

Today it is usual to listen to sentences that reflect the most common uses of education: is politeness outdated? Where is civic behaviour? 
Where is courtesy? Is it useful to respect social norms? Kindness is not rewarded, and it is not usual. Now, more than ever, ignorance is daring and it is excused as if it was naivety; "that boy does not seem to be educated; it is necessary to "polish him up", that is, it is necessary to make him better; this boy is badly brought up". All these sentences stress the most traditional statements of the common use of 'polite'.

The most traditional forms which the common use makes of the meaning of education come from our historical and collective experience; in very different authors and historical passages we find arguments which have been transmitted as collective cultural heritage and are part of the collective experience and the memory which identifies education in the following common uses: 1) education is courtesy; civic behaviour and urbanity; 2) education is material and spiritual upbringing; 3) education is improvement; 4) education is formation.

In short, the criteria related to the use of common language are grouped in four sections: criteria of content, form, formative use and balance (Esteve, 2010, pp. 21-28; Peters, 1969 and 1979; Touriñán, 2015; SI(e)TE, 2016):

a) Something is education because it obeys to axiological criterion of content: those processes in which we learn something that goes against values are not qualified as educational, which means that only the learning of axiologically irreproachable contents is qualified as educational. Defending something as educational involves a value judgement about the content which is used. If we do not achieve this, we are simply in process of communication, teaching and learning

b) Something is education because it obeys to ethical criterion of form: acting on educatees without respecting their freedom or dignity as persons is not considered educational. The educational process has to respect the educatees' dignity and freedom, because they are also the agents of their own development. If we do not achieve this, we are in process of instrumentalization

c) Something is education because it obeys a criterion of formative use: those kinds of learning in which educatees repeat something that they do not understand and that they do not know how to use is not described as educational. The educational process must make it possible for the educatee to develop some type of conceptual diagram about what is communicated. If we do not achieve this, we do not educate, we are only in processes of information, instruction, training and memory dexterity

d) Something is education because it obeys a criterion of balance for development: talking about education demands the achievement of an integrated personality avoiding situations in which the excessive or unilateral development of one of the areas of experience generates unbalanced men and women. The educational process always demands balanced results. Whether we speak about general formation or skilled formation, we speak about formation built on the principle of balanced education. If we do not achieve this, we do not educate, we are in process of specialism.

\subsection{Knowing, teaching and educating do not mean the same thing. Knowledge of education determines the concept of education field over knowledge of cultural areas}

The level of the current pedagogical investigations allows us to say that there are enough reasons to distinguish and not to confuse in the technical language:

\footnotetext{
- Knowledge of education, and

- Knowledge of cultural areas.
} 
It is true that, from an anthropological point of view, education is culture and, therefore, it makes sense to affirm that the function of the professional of education is to transmit culture. But, if we also affirm that the educational terms have no own content, knowledge of the diverse cultural areas is converted into the axis of all pedagogical activity to the point that the same professionals of education accept that their training is simply knowledge of those cultural areas, and that knowing, teaching and educating would be the same thing. For me, by principle of meaning, knowing a cultural area is not teaching, because knowledge can be separated from action and teaching is not educating, because we can affirm that there are teachings that do not educate, based on the meaning of those terms (Touriñán, 2016 y 2017b; SI(e)TE, 2016).

Regarding to cultural areas, it is true that knowledge of the cultural area is a component of educative action, but knowledge of cultural area has a different role when we speak of "knowing a cultural area", "teaching a cultural area" and "Educating with a cultural area". What we say, is obvious, if we think of a specific case, because it is not the same "to know History", "to teach History" and "to educate with History", and so on with each area of experience which constitutes an object of teaching and field of education.

From the point of view of knowledge of education, the teacher requires a certain level of training related to the knowledge of the area to be taught (area of experience and forms of expression appropriate to the area), but hence no it follows that teaching an area is the same as knowing the area, nor is educating the same as simply teaching the contents of that area. Depending on level of placement in the educational system in which the teachers carry out his job, it is undeniable that, regarding the current development of educational knowledge, they do not all require the same level of expertise on the cultural area of experience they teach (it varies depending on its level of placement in the educational system), and also it is undeniable that all teachers should not have the same pedagogical knowledge, because the required technical knowledge varies depending on the level of the educational system in which they work.

Knowing, in the broad sense of performance identified with the expressions "I know what, I know how, and I know how to do", is not confused with teaching. Aptitudes and competences to know and aptitudes and competences to teach are not subsumed one into another, nor they do both empty the meaning of the expression "educate with" a cultural area (Touriñán, 2015, 2019c, 2018 y 2017a). A detailed analysis of pedagogical context gives cause for maintaining knowledge of cultural areas and is not knowledge of education, because (Touriñán, 2017a):

a) Although it is true that a great part of the aims of education have something to do with the contents of cultural areas, the scope of the objectives is not drained in the fields of cultural areas. Pedagogical function, referred to teaching, is not drained in knowing which level of cultural information is being obtained when developing a topic of a cultural area in a class; however, pedagogical function becomes apparent when it is known which types of skills, habits, attitudes, et cetera, from the diverse domains the taxonomies mark are being promoted upon working in a special way on that topic. The question, in teaching, is not to know as much about an area as the specialist, but to know what knowledge objectives are achieved and how they are achieved when teaching a subject in the area and what skills, habits, attitudes, knowledge and competencies we are developing when teach that topic.

b) The identification of knowledge of the cultural areas with knowledge of education promotes an unsustainable pedagogical situation: the tendency to evaluate the scholastic 
efficiency fundamentally for the levels of cultural information. Without meaning that the content is merely formal and serves to reach any kind of skill, it is possible to assess that, although not with the same level of efficiency to form a pedagogical point of view, with just one of the cultural topics of the curriculum that a secondary level student has got to study, for example, pedagogical strategies leading to the achievement of almost all the educational objectives of the curriculum could be started, except for cultural information.

c) Even if knowledge of education and knowledge of cultural areas are identified, one could understand that, speaking in the field of teaching, there is a determined knowledge of education which is not the knowledge of cultural areas: knowledge about the transmission of knowledge content acquired on the cultural area. The duty of education would be indeed, for example, the transmission of the historic knowledge. In this case, this historic knowledge would be reliable and valid as a problem for historians and researchers from that cultural area; for teaching, knowledge of education would be, more precisely, the knowledge of the strategies for the intervention.

d) Considering the above, it is obvious that we need different competences for educating and teaching, and those are different competences of one which are required to know a specific cultural area. In effect, the theoretical, technological and practical knowledge which becomes instructional objectives in teaching are not created by the education professional; it is the researchers of each cultural area who create them. It is up to the education professional, based on technical choice, to decide: if the student can learn them; if they are consistent with the conceptual representation of the educational intervention; if they have a theoretical, technological and practical foundation, as the case may be, in knowledge of education to be used as an instrument of education; what level of content is appropriate in a specific case, what is the appropriate teaching method and what skills, habits and attitudes, knowledge and educational competences can be developed with the teaching of this knowledge. That is to say, the education professional masters theoretical, technological and practical knowledge of cultural area to be taught, at a sufficient level to teach them; But, as an education professional, he masters the knowledge of education that allows him to justify and explain the conversion of this knowledge of a cultural area into an objective or instrument of pedagogical intervention

e) From the point of view of educational competence, the key to the knowledge which is valid to educate is not in the domain of cultural areas, as if it were the specialist in that cultural area (artist, historian, chemist, or others), but in the domain of pedagogical competence which enables them to see and use cultural content as an instrument and goal of educative action in a specific case, in such a way that the cultural content is used as an instrument to develop in each student the character and sense which are inherent to the meaning of 'education'. Knowledge of education enables the education professional, for example, not only to establish the educational value of a cultural content and participate in the process of deciding its conversion into an end or goal of a singular educational level, but also to establish programs of intervention adjusted to facts and pedagogical decisions which make the proposed goal effective.

Speaking about knowledge of education does not imply questioning directly about the knowledge of cultural areas. When we speak of "knowledge of education", it is more appropriate to ask why certain knowledge constitutes a goal or instrument of educational action or why the cognitive dimension of man is educable. And as well as the knowledge of each cultural area, the historian, the geographer, the mathematician, the physicist, the art critic, et cetera, could 
speak to us, depending on the case and with property, because they are specialists in each of these cultural areas, there is no doubt that responding adequately to whether this or that historical, mathematical, physical, artistic content, et cetera, should constitute the content of the educational action that we carry out with a certain agent, or how to cultivate their critical sense, requires questioning about of education as an object of knowledge.

In the first case, the knowledges of cultural areas: history, mathematics, physics, etc., are the scientific object of study; In the two cases of the second assumption, the transmission itself and the improvement of the ability of knowing become a specific object of scientific reflection in the form of Didactics and Cognitive Pedagogy, as the case may be. And so it is, knowledge as an object of education requires research on education, that is, it requires that education become an object of knowledge, either as cognitive pedagogy or as didactics, respectively, but, in addition to responding to what a certain educational event took place and how a certain educational event can be achieved, we must also respond to how that event is justified as an educational event and this is a question that can only be answered by means of Pedagogy, from the knowledge we have achieved about the concept and the meaning of 'education'. That is the question from Pedagogy, not to improve our way of knowing, nor to improve our way of teaching, but the question of education itself from concepts with intrinsic (autochthonous) meaning to the field of knowledge 'education'. Knowing a cultural area is not teaching, because, as we have just seen, the competencies that are required in each case are different and teaching is not educating, because we can affirm that there are teachings which do not educate, based on the right meaning of both terms.

We must assume without prejudice that pedagogy is knowledge of education and this is obtained in various ways, but, ultimately, that knowledge, by principle of significance, is only valid if it serves to educate; that is, to transform information into knowledge and this into education, from concepts with intrinsic significance to the field of education. On the one hand, you have to know in the broadest sense of the term (I know what, I know how and I know how to do it); on the other hand, it is necessary to teach (which implies another type of knowledge different from knowing cultural experience areas; teaching implies making others know). And, as if that were not enough, in addition, it is necessary to educate, which implies, not only knowing and teaching, but also mastering the character and sense of the meaning of 'education', in order to apply it to each area of cultural experience we use to educate. When we comprehend cultural experience area from the specific pedagogical mentality and the specialized pedagogical approach (look) ${ }^{1}$, our intellectual concern allows us to distinguish between "knowing History", "teaching History" and "educating with History",

$1 \quad$ Pedagogue is responsible for making the intervention with a specialized approach (look), in order to get a critical vision of his method and his actions, and with a specific mentality, in order to integrate theory into practice and solve the problem of educating in each interaction. Pedagogical mentality is a mental representation that the pedagogue makes of the action of educating from the perspective of the theory-practice relationship; refers, from the perspective of action, to the capacity of solving education problems which is attributed to the knowledge of education in Pedagogy, regarding each one of knowledge of education currents.

Pedagogical mentality is a specific one. It is not a general one about life, but about education as a cognisable and attainable object. Neither is it a philosophical mentality about cosmovisions of the world, of life in general or about the diverse senses of way of life, nor should it be confused with the educational mentality which is adjusted to criteria of meaning and temporary formative orientation of educating. The pedagogical mentality is a mentality founded on education as an object of knowledge and therefore on the knowledge of education.

Pedagogical approach (look) is the mental representation that the educational professional builds about their technical performance, that is, on their performance as pedagogical; it corresponds to the critical scope that the pedagogue has about his method and his acts; this critical vision is based on principles of intervention and principles of education.

Pedagogical approach (look) is, therefore, a specialized one: it is focused on the problems of education and the technical competence of making a pedagogical approach depends on the knowledge of education which has been acquired. 
understood as a matter of cultural area which is part of the curriculum together with others and it has become from Pedagogy in an education field.

Field of education, as used in this context of argumentation, is not a physical space, but a concept derived from the educative valuation of the area of experience that we use as an instrument and goal of education. Education field is the result of the educative valuation of the area of experience that we use to educate and that is why are integrated, from Pedagogy, in the concept of field of education: the meaning of education, the intervention processes, the dimensions of intervention and the areas of experience and forms of expression along with in each technical acceptation of education field.

Field of education, which is always an expression of the cultural area valued as an object and instrument of education, integrates, as a concept, the following components: area of experience with which we are going to educate, convenient forms of expression to educate with that area, criteria of meaning of education reflected in character and sense traits inherent to the meaning of educating, general dimensions of intervention that we are going to use in education, educational processes that must be followed and technical acceptation of 'field', regarding education. Integrating these components is what makes the knowledge of education with each cultural area in order to speak with conceptual property of educating "with" a cultural area as a different concept of teaching a cultural area and knowing a cultural area which is part of the curriculum.

If we do not confuse knowledge of cultural areas and knowledge of education, it is not true that the teacher is a learner of the cultural areas that he teaches, nor is it true that necessarily the one who knows the most Art is the one who teaches it best, nor is it true that the one who best masters a skill is the one who best teaches another to master it, unless, tautologically, we say that the skill that masters is that of teaching, nor is it true that, when someone is teaching, it is always using cultural content as an instrument for achievement of character and sense proper of the meaning of education, because teaching is not educating. It is the objective of Pedagogy to transform information into knowledge and knowledge into education, building education fields from different cultural areas, and precisely for this reason we can say that Pedagogy is responsible for valuing each cultural area as education and constructing it as a "field of education" (Touriñán, 2020c; SI(e)TE, 2020).

This is so, because each of these activities requires different competencies and skills for its mastery, and practice and perfection in one of them does not automatically generate mastery of the other. In logical rigour, it must be accepted that knowledge of education is, therefore, a specialized knowledge which allows to the pedagogue to explain, interpret and decide the appropriate pedagogical intervention for the cultural area that is the object of teaching and education, as the case may be.

\subsection{The Concept of Education Is Nominally Related to a Criterion of Finality in the Activities}

In the field of educational knowledge and from the perspective of activity, we can affirm that the activities which we carry out do not determine the real meaning. The same activities which we perform to educate are done for many other things, so activities do not identify the educational action. In education we teach, coexist, communicate and take care, but educating is not each of these things separately, or all of them together:

- $\quad$ Any type of influence is not education, otherwise influencing a person to stop them from doing what they must do to be educated would also be education 
- $\quad$ The fact that any type of influence is not education does not nullify or invalidate the possibility to turn any type of influence into an educational process. Logically, nothing prevents educatees, through themselves and through the experience that others communicate them (self-education process) or by means of the experiences that others communicate them (heteroeducation processes), from analysing that negative influence with well-founded criteria on the educational knowledge and from turning it into a process of educational influence. It is not educational to manipulate or transmit as true the knowledge of a cultural area which the theoretical investigation of the area proves to be false. However, it is indeed educational to unmask manipulation and to use false knowledge to prove its error and exercise skills in the use of the theoretical proof criteria

- $\quad$ The fact that any type of influence is not education, but it can turn into a process of educational influence, does not nullify or invalidate the possibility to obtain educational results by means of influence processes not exclusively oriented to educational aims (informal processes).

From the perspective of the activities, distinguishing any other type of influence and educational influences, demands the pedagogical assessment of different ways of behaviour, considering the finality criterion. Coexisting is not educating, as there are kinds of coexistence that are not specified or described as educational. Communicating is not educating, since communication is always a physical and symbolic process whose purpose is to elucidate the message which the speaker aims at and the speaker does not always aim at education. Knowing a cultural area is not teaching, as knowledge can be separated from action and teaching is not educating because we can affirm that there are some types of teaching which do not educate, etc.
From the point of view of finality, education is value, because the finality is a value that you choose. As a value, the main aim of education as a task, is the development of skills, habits, attitudes and knowledge that qualify people to choose, engage, decide, perform and relate to values, because the task aims to build axiological experience. From that point of view, the main aim of education, as an achievement, is the acquisition of a set of behaviours that qualify educatees to choose, engage, decide and perform their personal life project in the educational process by using the axiological experience to give an answer to the requirements that arise in each situation in accordance with the opportunities. Concerning achievement, the aim is to use the axiological experience as an instrument of self-construction and formation: it is an activity oriented to construct oneself and recognise oneself with the other in a diverse cultural environment of interaction by means of values.

At this point, we can say that the educational activity is "educational" because its aim is to educate and it adjusts meaning to the criteria of common use of the term, like any other object which is defined and comprehensible. From a descriptive or expositive point of view which takes into account the activities previously mentioned, the aim of education is to make educatees acquire knowledge, attitudes and skills-abilities-habits which qualify them, from each activity to decide and perform their projects, by giving an answer to the requirements that may arise in each situation in accordance with the opportunities.

\subsection{It Is Necessary to Go beyond Common Use and beyond Activities Which Correspond to Nominal Definition}

The common use of the term education helps us to form the concept in such a way that we are able to distinguish between what educating 
is and what it looks like and this is important, since it is possible for certain activities to look like education and to be a different thing. The analysis of the activities helps us to specify more; we not only discern (know its appearance and configuration), but we advance towards the definition of the specific traits of education. Apart from knowing that something is education, it is necessary to be able to say what education is. It is necessary to know what a thing is, unlike another which 'is', as well. It is necessary to explain all the physiognomic traits of the thing. Then, we not only discern a thing from its appearance, what it is from what it is not, but we also circumscribe the limits where education begins and finishes precisely, that is, its unitary profile. The criteria of common use of the term and the criteria related to the activities allow us to discern and link the definition to the finality: the concept of education is demarcated whenever the criteria of common use of the term are achieved and the finality of educating is preserved (Touriñán, 2015 y 2014a).

However, nothing previously mentioned allows us to establish with certainty which are the specific aims which have to be related to what the product of education is and to the temporary formative orientation of each moment, adjusted to the individual, social, historical and speciesbeing human condition. Apart from discerning, knowing the appearance, it is necessary to define the typical traits of education and try to understand them in their functioning, because knowing what education is implies knowing how to discern and knowing how to define and understand the concept. This demands to go beyond the criterion of common use of the term and the criterion of activity as a finality to understand the distinctive traits of the character of education and of the sense of education that qualify and determine its real meaning in each educational act.

Etymology and synonymy constitute the sphere of nominal definitions. In this sphere we are able to reach a kind of knowledge that allows us to discern. We can even go deeply into the stipulative, descriptive and programmatic uses of the general definition (Scheffler, 1970). Knowing is not only discerning; it is necessary to be able to define by looking for the traits that allow us to distinguish what it is from what it is not. The common use of the term education helps us to form the concept, so we are able to distinguish what educating is from what it looks like.

The analysis of the activities helps us to specify more: not only do we discern (know its appearance and configuration), but we advance towards the definition of the specific features of education. In addition to knowing that something is education, it is necessary to say what education is. It is necessary to know what a thing is, unlike another which 'is', as well. Nevertheless, the analysis of the activities allows us to affirm that the activities which we perform in education are not those that determine the real meaning. The same activities that we carry out to educate are done for many other tasks. We have criteria of use of the term which let us discern, but we only reach the sphere of the real definition, if we go into the traits that characterise the thing to be defined. The way to the real definition starts with the analysis of the activities which enables us to preserve the finality, but it goes further.

In the context of education, nearly all the definitions of the term move between the nominal definition (etymological or synonymic) and the connection with the finality of the uses of the term. It is a frequent practice to define by following previous definitions given by other authors and extract the features which adapt best to the particular position of the context that we want to defend, as if they were expositive or descriptive definitions. Very varied works compile multiple definitions of education which adjust themselves to this way of defining (Sáez, 2007; García Aretio, Ruiz Corbella and García White, 2009). 
However, this way of acting has sometimes led to an excessive formalism in the context of definition, because, by trying to look for meanings of common use which are accepted in general, these definitions do not engage with specific uncommon situations and avoid being related to the previous uses in particular. On other occasions, the definition frequently ends in unconcerned eclecticism, since these definitions do not try to reconcile or confront the doctrines of the numerous currents about the different meanings compiled, but they try to emphasize the features which are considered denotative and which form the concept (Quintana, 1988, p. 51; Berlo, 1979, pp. 209-228). If educating implies turning animality into humanity, in how many ways can we do it?; If educating is giving the body and the soul all the perfection of which they are susceptible, how can we identify, discern, define, create or develop this perfection? If education is intentional improvement of the specifically human capacities, are all man's capacities human or are there any that are typical of man, but which are not human and, therefore, which would not have to do with education?

We have to go beyond the nominal definition: apart from discerning, knowing the appearance, it is necessary to define the typical features of education and it is necessary to try to understand them in their functioning. This demands to go beyond the criterion of common use of the term and the criterion of activity as a finality to understand the distinctive features of the character of education and of the sense of education which qualify and determine its real meaning in each educational act. However, the truth is that instead of following this path, a large part of the pedagogical thinking is inclined to follow the metaphorical thinking, compatible with the pedagogical antinomic thinking. (Mantovani, 1972).

Moving from the nominal definition to the real definition requires discovering the typical features of education and understanding them in its functioning. It is necessary to explain all the physiognomic features of the thing which is defined. Therefore, not only do we discern a thing from its appearance, what it is from what it is not, but we also circumscribe the limits where education begins and finishes with precision, that is to say, its unitary profile, since knowing what education is implies not only discerning, but also knowing how to define and understand the concept.

We have to reach the real definition because the truth of every definable thing is based on itself, on its particular features which justify it as such, because they confer it character and sense, determination and qualification against any another thing that is and has the properties that belong to it by logical necessity. Understanding is not only noticing the set of traits offered to the one who observes, but explaining them as traits which have previously constituted the thing in question; it is necessary to understand why this thing is that way and not another way. When knowing things in this way, we know about their need to be the way they are and, therefore, why they are not another way. When defining traits and understanding them, we know in the full sense of the word: 1) we show the logical need for some characters or constitutive traits, 2 ) we reason theoretically and practically about its principles and 3 ) we measure the impression of reality that they transmit us (Zubiri, 1978, pp. 39-44).

Knowing in a deep sense is knowledge with coherence and critical sense. It is knowledge, which is close to wisdom, which always requires the personal integration of what we know. Assuming the competence of knowing in a broad sense has forced us to think about new revisions in the field of the research of new processes and environments for knowledge acquisition which are configured as personal learning environments (Reig, 2012), compatible with personal learning 
trajectories which orient new teaching theories (Stzajn, Confrey, Wilson and Edington, 2012) and serve to create funds of personal knowledge (González, Moll, and Amanti, 2005). They are types of specific learning that affect the cognitive capacity, the information processing and the affective-emotional and social competence from the perspective of situated and meaningful learning (Novak, 1998; Díaz Barriga, 2006; Polanyi, 1978; Ausubel, 1982)

Nothing of the nominal definition allows us to establish with certainty which will be the concrete aims that have to be related to what the product of education is and to the temporary formative orientation of each moment, adjusted to the individual, social, historical and speciesbeing human condition. The nominal definition does not help us either to accurately know which the structural components of pedagogical intervention are, since it does not let us go deeper into the objectual complexity of education. Nominal definition does not tell us anything about the capacity to solve theoretical and practical problems of the educational action, because it does not allow us to go into the capacity to solve problems of educational knowledge. None of these questions is a matter which is simply deducible from the idea of finality in a direct way. We must build the real definition. And that means answering a double foundational question: what all activities have in common to make it possible to educate and what are those traits inherent in the meaning of educating.

From the perspective of the real definition, distinguishing any other type of influence and educational influences, demands the pedagogical assessment of diverse ways of behaviour, paying attention not only to criteria of use and finality, , but also to understand the activity as a common state and capacity which makes the man to educate himself and also to attend to criteria of meaning intrinsic (autochthonous) to the concept of educación so that principles of education and principles of pedagogical intervention can be built through knowledge of education.

In short, we have to build the thought that allows us to justify that the educational activity is "educational", because: 1) it adjusts to the criteria of use of the term, 2) it fulfils the finality of educating in its activities and 3 ) it adjusts to the real meaning of that action, that is to say it adjusts to its typical traits of character and sense, like any other entity that can be defined and is understandable.

To be able to affirm that something is really educational and is education, we have to ask ourselves:

- What we can do with all the activities to turn them into education?

- What we can do to make an artistic activity be educational?

- What we can do to turn a certain content of cultural area from information into knowledge and from knowledge into education?

- What we can do to teach a cultural area in some cases and to educate with the cultural area in other cases?

- What we can do to turn an area of cultural experience into a field of education?

- What we can do to build an educational field integrated into the curricular architecture?

We have to advance from discerning, knowing the appearance, to defining the particular traits of education and to understand them in their functioning, because knowing what education is means discerning, defining and understanding. All the types of the education specified (mathematical, environmental, intellectual, physical, affective, professional, virtual, etc.), are education because they are, generically, education and this means that they 
have in common the particular features that determine and qualify an action as education and, in each case it is performed as a specific and programmed educational action which takes into account each of the structural elements of pedagogical intervention.

From the point of view of the real definition, "educating" demands to speak about education, taking into account the distinctive traits of the character of education and of the sense of education which determine and qualify its actual meaning in each educational act. Educating is carrying out the meaning of education in any educational field, by developing the general dimensions of intervention and the adjusted competencies, the specific capacities and the basic dispositions of each educatee to achieve knowledge, attitudes and skills-abilities- habits related to the finalities of education and to the guiding values derived from these aims in each educatee's internal and external activity, using for this the internal and external means suitable for each activity, in accordance with the opportunities (Touriñán, 2015, 2014b).

From the point of view of the real definition of education, we have to advance in the knowledge of all these distinctive traits and it makes sense to ask oneself where education is and how we achieve the knowledge of its distinctive traits, as it is necessary to go beyond etymology, synonymy and finality to reach the real meaning and to be able to establish principles of education related to the character and the sense inherent in the meaning of education, and principles of intervention linked to the structural elements of the intervention, taking into account the commonalty of the activity.

Principles of education and principles of pedagogical intervention are not the same. The principles of pedagogical intervention derive from the structural elements of intervention (knowledge of education, pedagogical function and profession, educational relationship, education agents, processes, products and means). The principles of education are related to the character and to the sense that are inherent in the meaning of 'education'. As we will see in next epigraphs, the specific character of the meaning of 'education' comes from the objectual complexity of 'education'. Objectual complexity, which comes from the diversity of man's activity in the educational action, can be systematised from the axes which determine the features of character of education. Sense, which belongs to the meaning of 'education', is inferred from the connection between the self, the other person and the other thing in each educational act and qualifies the meaning, taking into account conceptual categories of space, time, genre and specific difference. From the point of view of character and sense, it is said that all educational action is of axiological, personal, patrimonial, integral, gnoseological and spiritual character and that all educational action has territorial, durable, cultural and formative sense at the same time. Since we can develop a conceptual system in education based on its real definition, Pedagogy develops principles of education, adjusted to the traits of character and sense of education, and principles of intervention, adjusted to the structural elements of intervention. The principles of education, derived from the character and the sense of education, support the educational aims; the principles of intervention support the action. Both principles have their own place in the achievement of the controlled educative action.

This reasoning makes us face the challenge of going beyond the nominal definition and the activity with a purpose: apart from discerning (knowing the appearance) it is necessary to define the typical traits of education and it is necessary to try to understand them in their functioning. This demands to go beyond the criterion of common use of the term and the criterion of activity as finality and to focalize on what the activity has in common as capacity to 
educate and on the distinctive traits of character and sense of education that qualify and determine its real meaning in each educative act. We are going to advance in this challenge by facing two issues: 1) the analysis of the activity as capacity, from the perspective of the pedagogical function and 2) the systematization of the character and sense traits of 'education' which determine and qualify its meaning.

\section{THE PEDAGOGICAL FUNCTION GENERATES INTERVENTION BY MEANS OF INTERNAL AND EXTERNAL COMMON ACTIVITIES}

In education we carry out many actions in order to influence the educatee and achieve the educational result. They are always mediated actions of one subject with another or of a subject with himself. And all those actions, which must respect the condition of agent of the educatee, seek to provoke the activity of the educatee. In its most common use, 'activity' is understood as a state of activity, it is activity-state: activity is the state in which any person, animal or thing that moves, works or executes an action is found at the moment he is doing it (we say: this child is thinking). This use also refers to the capacity we have for action in that activity and this is why we can say the child has lost activity (now he thinks less, he has dropped). Because it is the most common use of the term 'activity' as state and capacity, we denominate it common activity and it occurs in all people because in all people there is activity as a state and as a capacity to do (Touriñán, 2014a and 2020a).

Regarding common activity, we have to say that current research distinguishes between actions carried out to obtain a result and actions whose result is the action itself. Thus, for example, the action of solving a problem results in something "external" to the action: obtaining a solution (studying results in mastering a subject). In all these cases, the action of solving the problem and having it already solved cannot be carried out. However, I cannot feel without feeling, think without thinking, project without projecting, et cetera. The former are external activities and the latter are internal activities. We, from now on, will talk about education, of common activity (state activity and capacity) internal (result is the action itself: thinking, feeling, wanting, operating, projecting and creating) and external (activity, state and capacity, whose result it is external to the action itself, but conceptually linked to the activity itself: I have the ability to play, I have the ability to study, I have the ability to work, to intervene, to inquire-explore, and I have the ability to relate).

From the perspective of common internal activity, we can make a taxonomy of activities taking the educating agent as a reference. We all agree that, when we educate ourselves, be it self or hetero-education, our human condition allows us to carry out the following internal common activities: thinking, feeling affectively (having feelings), wanting objects or subjects of any condition, operating (choosing-doing things by processing means and ends), projecting (deciding-acting on internal and external reality by orienting oneself) and creating (building something from something, not from nothing, symbolizing the notation of signs: realizing something -to note- and giving it meaning -to mean-, building symbols of our culture). Nobody is educated without thinking, feeling, wanting, et cetera To educate oneself is to always improve that internal common activity and know how to use it for specified instrumental activities that make us increasingly capable of deciding and carrying out our projects.

We also agree that, when we educate ourselves, our human condition allows us to carry out the following external common activities: play, work, study, intervention, inquiry-exploration and relationship (friend, family member, partner, social, et cetera). They are common activities (state and ability) because I have the capacity 
for study, play, work, exploration, intervention and relationship. And they are external common activities, because they necessarily have a result to be obtained, which is external to the activity itself, but which is conceptually linked as a goal to the activity and characterizes it as an identitary trait. Hence, we say that studying is having and organizing written information "for" their mastery (mastering or knowing the subject of study); The domain-knowledge of the subject of study is the external result of the activity and this result is the finality which identifies the study, regardless of whether I can use the study to make a friend, to altruistically help another, to steal better, et cetera, which are uses of the activity as instrumental specifications of it (Touriñán, 2016).

As an external common activity, studying, for example, has its own purpose linked to that activity in a conceptual and logical way (the proper finality of studying is to master-know what is studied: information, content or the study technique itself). But, in addition, as an external common activity, studying can become a specified instrumental activity for other purposes, they are specified purposes and external to the activity itself, but linked to the activity of studying in an empirical or experiential way (studying becomes an instrumental activity specified, because we can study to steal, to make friends, to help another, to educate ourselves, et cetera) (Touriñán, 2019a).

It is a fact that common activities are used propaedeutically for educational aims, but they can also be used for other purposes. Common activities can be used to perform instrumental specified activities and they have propaedeutic value; they are preparatory for something later. And this is so, on the one hand, because everything that we use as a means in a meansend relationship, acquires the proper condition of the means in the relationship (the means is what we do to achieve the end and the end is a value chosen as the goal in the means-ends relationship) and, on the other hand, it is so, because the means shows its pedagogical value in the conditions that are proper to it, adjusting the means to the agent, the educational aims and the action, in each circumstance (Touriñán, 2020b).

From the perspective of internal common activity, we can say that activity is principle of education, because no one is educated without thinking, feeling, wanting, et cetera And from the point of view of external common activity, we can say that we do many activities whose purpose is to 'educate'. Always, from the perspective of the principle of activity as the guiding principle of education: we educate with activity respecting the condition of agent (Touriñán, 2015).

If this is so, it follows that the means have to adjust to the activity of the subject and the meaning of education. They are means for a specific subject who thinks, feels, wants, operates, projects, and creates. They are means to carry out activity, playing, working, studying, inquiring, intervening, and interacting. But the agent performs these activities to educate himself: he does not think in any way, but of the one that is built to educate himself and act educatedly, and so on with all activities. It follows, therefore, that any medium is not "the means" for a specific subject; In educational action, the educatee-subject acts with the internal means that he has and with the external means that have been made available to him. And all those means are only educational means if they serve to educate that educateesubject. The means are not exactly the same if I want to train the critical sense, or if I want to educate the will to produce strength of mind. This is precisely why the tendency to focus on the specific and particular means of an action is explained, forgetting the common and shared means with other educational activities.

Activity is present in all education: from one perspective, as a principle of intervention and, from another, as a principle of education. And 
precisely because this is so, it is explained that the activity becomes the backbone axis-principle of education and represents the real sense of the meaning of education as an activity aimed at the use and construction of valuable experience to generate educated activity. We use the common activity to educate; we educate the appropriate competencies of the common activity and hope to get educated activity. In short, we use the activity in a controlled way to achieve educated activity and educate the activity through the appropriate skills (Touriñán, 2016).

The principle of activity is neither passivity nor activism; it is the use of the activity in a controlled manner to act educatedly. And in this way, activity and control are principles of pedagogical intervention, derived from the condition of an agent who has to construct itself and recognize itself with the other person and the other thing in a diverse cultural environment of interaction, through values he has to choose, commit one self, decide and effect, executing through concrete action what is understood and interpreted in the means-end relationship, expressing it, according to the opportunities.

This is so because, as a principle of activity, no one is educated without thinking, feeling, wanting, operating, projecting and without being creatively interpreting symbols of our culture. We educate ourselves with internal common activity. But, in addition, we educate ourselves through external common activity ( studying, playing, working, inquiring-exploring, intervening and relating to the self, the other person and the other thing), because by exercising a specific external common activity we activate the internal common capacities, we train them, we exercise them, we drill them and we improve them to do well each external common activity. The external common activity, by principle of activity, activates the internal common activity in each specific execution of the external common activity, whatever it may be (playing, studying, working, inquiring, intervening, or relating). By executing the external common activity, we improve and train the internal activities-capacities: without the activity it is impossible to educate and through the activity it becomes possible for the educatee to be an actor-agent and an increasingly better author-agent of his own projects and acts.

The principle of activity allows us to affirm in Pedagogy that external common activity (for example, playing) activates the internal common activity of thinking, feeling, wanting, operating, projecting, and creating, but that does not mean falling into activism: do activity just for the activity does not educate; to think in any way is not to educate oneself, since getting educated, at a minimum, requires that, when we are thinking, the habit and way of thinking has to be improved.

For all that, education is everyone's problem and we all contribute to it because we all have to become educated and we have to use common activity to educate and educate ourselves and it is not possible to do so without it.

\section{OBJECTUAL COMPLEXITY AND CHARACTER OF EDUCATION: AN UNAVOIDABLE REQUIREMENT IN THE REAL DEFINITION}

In the field of the research methodology there is a basic principle: the principle of objectual correspondence. The method depends on the object or on the aspect of reality which we intend to know. Directly and indirectly, pedagogical research has made progress by assuming that objectual correspondence is a condition of methodology: the method must adapt to the objects that it researches (González Álvarez, 1947). Objectual correspondence implies that the method depends on the object or on the aspect of reality that we intend to know, therefore, it is true that the method cannot be formulated before undertaking the study of the object because a method described as a priori is usually unsuitable for the object; it is also true 
that we cannot go further in the study of the object without acquiring a method, because we will act in a disorganised way (Colbert, 1969, p. 667). We are methodologically forced to advance in the theoretical development of the object of research by the principle of objectual correspondence.

In the year 1947 Professor González Álvarez, stated this fundamental principle of methodology: "all science, as a human product, depends on two fundamental factors: the object which it deals with and the subject which elaborates it. This implies this fundamental truth: the method of a discipline has to be congruent with the noetic structure of the object that it researches and be adapted to the cognitive contexture of the subject that receives it" (González Álvarez, 1947, p. 10). On the one hand, this statement confirms that any method is not useful for any kind of research and on the other hand it confirms the need to adapt to the conditions under which the truth is offered to us. In the case of educational relationship, it is necessary to understand that the relationship is only singularised if the complexity of the object education is taken into account and if we assume the traits of character that determine a singular and specific action as 'education'.

\subsection{Objectual Complexity Is Related to the Agent's Internal Common Activity and It Determines the Traits of Character of 'Education'}

Pedagogical research has to pay attention to the object of knowledge that is appropriate for it: education. In this determination, we are destined to complexity due to the particular condition of the object 'education' because very diverse aspects make education a complex object and the paradigm of the complexity helps to outline the conditions that make it be like this (Arendt, 1974; Lyotard, 1984; Prigogine, 1997; Prigogine and Stengers, 1983; Lipovetsky, 1986; Touriñán and Sáez, 2006 and 2015; Luhman, 1983; Maslow, 1982; Bateson, 1979; Damasio, 2010; Pinker, 2003; Zubiri, 2006).

The displacement which has occurred in Epistemology at present clearly shows that the essential does not consist in eliminating perspectivist interpretations, but in "the production of a way of totally critical knowledge, that is to say, which is able to control each of its processes, to consciously set its goals and to justify the procedures used to attain them" (Ladrière, 1977, p. 115). Objective knowledge must be able to be judged and therefore, must "pronounce on the value and the validity limits of what it finally proposes" (Ladrière, 1977, p. 115).

The variation that has been carried out aims at the interpretative conceptual system and its rationality rules are not given 'a priori': "Criticism also associates judgement and the construction of criteria in an inseparable way. It does not possess in advance the principles according to which it will be able to direct its appraisals; it builds its principles while it uses them (...) The implicit norms of science do not exist 'a priori', they are built and rebuilt continuously" (Ladrière, 1977, p.115).

According to Ladrière, the idea of mastery is perhaps the one that summarises the specific of this change from the concept of objectivity to complexity in a better way; mastery "represents the capacity to achieve the set goals and to gain independence from all external conditioning" (Ladrière, 1977, p. 120). The rationality of means requires the rationality of the set goals because it is not enough guarantee of knowledge to say that it does what "scientists usually do"; the objectual correspondence must always be present in each methodological action.

If we want to tackle the substantiality which is characteristic of the educational action as a whole, the knowledge of education is destined to critical and complexity paradigms owing 
to the methodology development, and to comprehensive positions which recognise the axiological character of facts and the factual condition of value owing to the evolution of the objectivity concept. We are destined to complexity because of the particular condition of the object 'education'.

The idea of simplicity that has always dominated the research methodology is not contradictory with the idea of complexity paradigms. Simplicity does not mean renouncing to explain a field with new concepts or reducing its explanation as much as possible from the concepts of other sciences. Simplicity is not considered an irrefutable principle, and certainly it is not a scientific result, because the simplest and sufficient explanation is the most probable, but not necessarily the true one. Its basic sense is that the simplest theories will be preferred in identical conditions, but a different question is to know which evidences will support the theory. Against the principle of simplicity, common sense suggests that a simpler theory but less correct should not be preferred to a more complex theory but more correct (Novak, 1998; Bunge, 1975, pp. 145-184). At this point, unless we defend erroneously that we do not want to attain new knowledge, or that knowledge has reached such a degree of perfection that it cannot be improved, it is necessary to admit that the same theories with which we face reality force us to value or reject data. We do not mean that data do not exist; what occurs exactly is that we do feel in condition not to pay attention to them.

Professor Colom, who has dedicated several works to the complexity of the object of knowledge 'education', summarises his position about the education complexity in his work "Pedagogy of the labyrinth" and tells us that 'education' is a complex object, because (Colom, 2008, p.10):

- $\quad$ Education integrates children, but they will have to restructure the things which they learnt
- Educational influences from different environments do not develop in the same sense and make evolution and development unpredictable

- $\quad$ The starting point is different for each educatee and the educational subject is imparted by different people

- $\quad$ The curriculum which serves to arrange education and learning leads to diverse practices, with which the education arrangement leads to differentiation

- $\quad$ School failure proves that the educational system is not so organized and predictable as it looks like.

For his part, Edgar Morin tells us that leading humankind to the knowledge of their own complex realities is possible (Morin, 2009, p. 18) and maintains that human knowledge is complex because (Moring, 2009, p. 17)

- Its sphere of observation and reflection is a really extensive laboratory

- $\mathrm{He}$ admits that the human subject he studies is included in his object

$\bullet$ He conceives human unity and diversity inseparably

- $\mathrm{He}$ considers that all the dimensions or aspects which are nowadays disjunct and compartmentalised in the studies on man are actually related

- $\quad \mathrm{He}$ keeps together disjunct truths which are mutually excluded

- He links the scientific dimension (verification, hypothesis, refutability) to epistemological and philosophical dimensions

- $\quad$ Knowledge must also be more scientific, much more philosophical and finally much more poetic than it actually is 
- $\quad$ It is necessary to find a sense to the words that have been lost and rejected by sciences, including the cognitive ones: soul, mind, thought.

For Morin, education assumes the human complexity in the educational action. Educational action is complex because both educatees and educators find possibilities for the self construction of their autonomy (Morin, 2009, p. 17):

- $\quad$ Through their capacity to acquire, to capitalize on and exploit their personal experience

- $\quad$ Through their capacity to produce strategies of knowledge and behaviour (that is to say, face uncertainty)

- $\quad$ Through the capacity to choose and modify their choice

- $\quad$ Through the capacity of consciousness.

For me, the complexity of the object of knowledge "education" comes from the diversity of the human activity in the educational action, whether we talk about competences adjusted to educate (talent, willingness, perseverance, mettle, personal development trajectory and creative vital tone) or we talk about internal and external common activity (activity as a state and capacity) and about specified activity (activity as a purpose task). This is because when we educate, we always look for competence to choose, to force oneself, to decide and to feel attained and attainable values as educational and all this requires cognitive integration and creative integration. Cognitive integration is required because it is necessary to relate ideas and beliefs to expectations and convictions in every action by using ways of thinking to articulate thought values and believed values with reality by means of knowledge and rationality. Creative integration is required because it is necessary to articulate value and creation in every action by connecting the mental and the physical in order to build culture by using symbols. Creative integration is a way of creative relationship between the self, the other person and the other thing, and an emergent consequence of the human connection between the mental and the physical in the brain, which makes it possible to create culture and symbols so as to note and signify reality and give an answer to the individual, social, historical and species-being human condition from our projects (Touriñán 2016).

To achieve all this in education, we sometimes focus on the intelligence, other times on feelings, others on willingness, others on intentionality, others on morality and some others on the creative spiritual sensitivity in order to make the creation of typical symbols of the human culture become effective. We, obviously, use resources for all this, and these resources are, in many occasions, the contents of the areas of experience, but in that case we must distinguish between knowing history, teaching history and educating with history, for example.

All this is the objectual complexity of "education", which has to turn into specific educational action in each case of intervention. The complexity arises from the activity diversity; we intervene by means of the activity to achieve educated activity, which means that we go from knowledge to action to form the individual, social, historical and species-being human condition, taking into account the characteristics of the object "education", which make it possible to identify its internal character determining traits. Activity is the central pillar of the complexity of the object "education".

Objectual complexity is a property of pedagogical research which makes us keep the connection of the individual, social, historical and species-being human condition with the object "education" accurately and deal with its characteristics. 
Their relationships make it possible to identify its internal character determining traits and face every intervention as knowledge and action, and as a connection between value, choice, duty, decision, feeling, thought and creation. The relationships that are established between those elements make it possible to identify the internal (character) determining features of education. Character is the distinctive feature or set of characteristics that determine something as what it is. The character of education is its determination, what determines it, which comes from the objectual complexity of education which demands to solve the relationships between value, choice, duty, decision, feeling, thought and creation which are typical of man's internal common activity and which are depicted in Chart 1.

Chart 1: Objectual complexity of 'education'

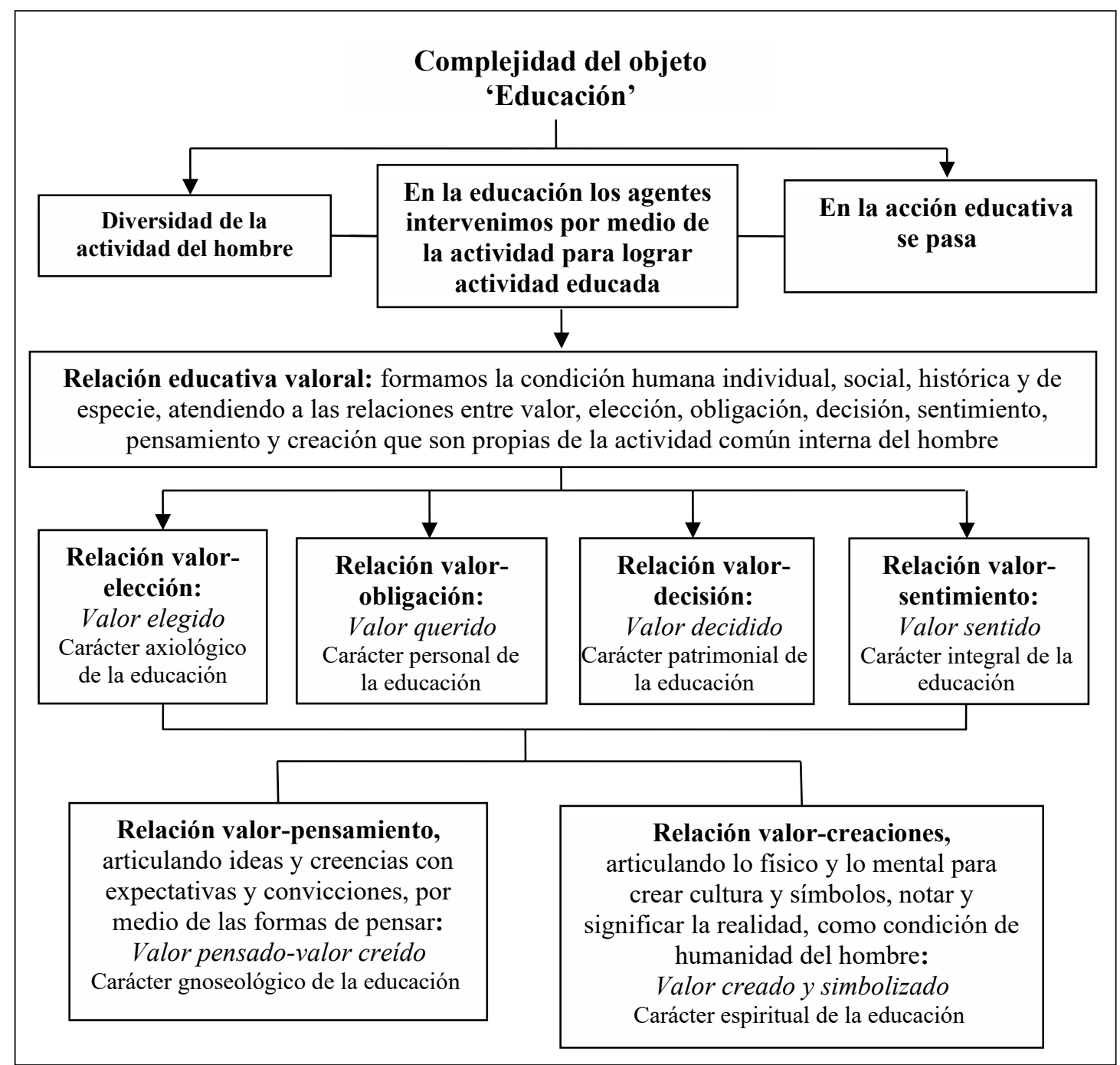

Source: Touriñán, 2014, p. 352. 
This is because the internal common activity of any human that is educated implies thinking, feeling affectively (having feelings), wanting objects or subjects of any condition, operating ("choosing to do" things by building processes and processing means and aims), projecting ("deciding to act" on the internal and external reality by guiding oneself, building projects and setting goals) and creating (building culture, building something from something, not from the void, by symbolising the notation of signs; performing something -note- and giving it meaning -signify- by building symbols of our own culture).

\subsection{Systematisation of Traits of Character Which Determine the Meaning of 'Education'}

In my opinion, it is possible to systematise the complexity of the object education from three axes that determine traits of character of education:

- $\quad$ The founding condition of values in education

- $\quad$ The double condition of agent-author and agent-actor of each subject concerning their education

- The double condition of field of knowledge and field of action for education.

Concerning the first condition, we have to say that education lacks all intelligible justification, when the fundamental character of values is rejected. As we all do not have to be necessarily the same in life, it is inferred that each one will only decide to fulfil themselves in a concrete way when it is possible for them to explain the value of that specific way to carry it out, by means of their own capacity and with the help of others. Besides, as men are neither born perfect, nor they reach the perfection which is characteristic of them spontaneously, it follows from this that they will not understand properly the value of fulfilling themselves in such a concrete way, unless education puts the necessary means for them to be able to build up the capacity of lucid choice. This relationship between education and values makes education in values be an inexorable need. Education is always education in values and choice of values and although any type of influence is not education, any type of influence can be changed into a process of educational influence. We have to know, appreciate and choose values; education is a value itself, it teaches values and, when we educate, we are choosing values, because we set goals and aims are chosen values. We give values a sense of action responsibly from the resolution of the means-aims relationship. The educational relationship, from the fundamental condition of value, acquires axiological character and is necessarily understood as education in values for the construction of processes and operative habits of choice that result in the creation of responsible sense of action, from the perspective of connecting means and aims.

The founding condition of value makes the object of knowledge 'education' be the way it is: chosen values. From the perspective of value, education involves a value-choice relationship, because we build aims and this means that we have to develop operative habits which allow us to connect the things that we choose and arrange them as means and aims. It is necessary to achieve operative habits which are connected to the sense of responsible action in each educatee. Responsibility and sense of action are principles of education related to its axiological character.

By means of the first condition, education acquires axiological character. Axiological character means that education is always education in values and choice of values and although any type of influence is not education, any type of influence can be changed into a process of educational influence. In each 
action we set goals, which are chosen values and we give them a responsible sense of action from the resolution of the means-aims relationship. Values are eligible, because we set goals which are chosen values. In this way, the axiological character determines education as a construction of processes, of a means-aims relationship.

Concerning the second condition, we have to say that the meaning of agent marks a trait of character in education which cannot be avoided, at the risk of renouncing to educate. We always think about educational relationship as a relationship between two, but the truth is that it is, in an unmistakable way, a relationship of one with oneself. In the educational relationship each of us are agents-actors who let ourselves be guided and obey those people who work as educators. We perform a lot of operations because we are guided to be educated. Besides, we are agents-authors because we guide ourselves in processes of education by deciding our goals and integrating our acts into our projects. By means of education we undertake the task to be actors and authors in our projects, even if our decision is to act as we are told. In each case, as agents, we are destined by education to undertake the task of being authors and actors of our own projects.

From the agents' perspective, the peculiarity of the educational action does not lie in the fact that the agents are one or two, but in the unquestionable truth that each person is, in a way, the agent -actor and author- of his/her own development and therefore we have to achieve volitive habits in educatees so that they may want things and engage in them by forcing themselves, and projective habits, which allow them to integrate things into their projects by identifying themselves with them and setting goals. Volitive habits relate to the personal commitment and projective habits relate to the sense of life. That is to say that I educate so that educatees can educate themselves and can decide and develop their life project and formation. We not only operate (we choose to do things, perform operations, act), but we also force us (voluntary commitment) and project (do projects, decide to act). In the educational relationship, educatees are also the subjects of their education, so they have to find the control of their own life by developing the patrimonial sense of their individual, social, historical and species-being human condition. I set goals, but I also force myself and control my choice autonomously by deciding the actions from my decided project, even if my decided project is to do what I am told. From the agents' point of view, education is made up of personal and patrimonial character and demands to understand the value-duty and value-decision relationship, since volitive and projective habits, together with the operative habit, have a place in the educational action (Ferrater, 1979, pp. 119-155; Dearden, Hirst, Peters, 1982).

By means of the second condition, education acquires personal and patrimonial character. The personal character of education means that the educational action respects the educatees' condition of agents. It prepares them to engage and force themselves personally (it is the genuine origin of their choice), in a voluntary way, in their performances and to invent or create original-singular ways (that arise in them and from them) of carrying out existence, by facing their human condition (individual, social, historical and species-being) with autonomy and responsibility, inside the shared space of a culture, and getting away from the repetition or cloning of pre-established models (Arendt, 
1974; Damasio, 2010; Gervilla, 2000, Haidt, 2006; Marina, 2009; Morin, 2009; Pinker, 2011; Mosterín 2008).

The personal character of education means that we force ourselves to act as it is appropriate, under the considerations of simple duty, urgent duty and fundamental duty, no matter what kind of rationality we have used to understand the situation. In addition to operative habits, we need volitive habits of commitment and personal obligation to the action. This marks the personal sense of education as a natural and original commitment, that is to say, born from oneself towards one's education, which has to be seen in relation to the existence of the other person and the other thing in each intervention. We are forced to be actors and authors in the educational action concerning oneself, the other person and the other thing. We engage with values voluntarily to comply with rules and norms. The commitment and the origin of the action in the person who is an agent are principles of education related to the personal character.

Patrimonial character means that when we set aims, we not only consider their value, but we also include that value in the aim as an integrating part of our life project; we create our own patrimony out of ourselves: we identify ourselves in the decision, we individualise ourselves and decide the sense of our life. Identity, individualisation and the sense of our life are principles of education related to the patrimonial character. Affirming the patrimonial character of education means that each of us is a patrimony; that we learn to choose, to engage and to decide our goals, which are integrated into our life project by giving an answer to our needs in each circumstance: we build ourselves as our more proper patrimony. Deciding which of our needs has to be dealt with in our life project, here and now, implies deliberating and assuming (attending to the knowledge, values, feelings, attitudes and interests that we have in that moment) a patrimony that we will be able to correct and vary thanks to the opportunities, the circumstances and the education received, but that we cannot avoid having in the moment we take the decision. Patrimonial character defines education as the setting of goals and the building of personal projects. The finality turns into a goal because it integrates into our projects.

Concerning the third condition, it is assumed that I can choose to do something, I can engage with that 'something' and I can even decide to integrate that 'something' as part of my projects, but then I must accomplish it, I must go from thought to action, I must go from the attained and attainable value to the effective accomplishment. From the third condition, it is necessary to insist on the fact that education is a field of reality which is susceptible of knowledge and an action which is performed by means of educational relationship. It could be said then that both methods of thinking and methods of action are advisable for education, in the most classic and universal sense of methods of theoretical and practical rationality (Mosterín, 2008b). This double condition identifies the complexity of the educational action for pedagogical knowledge, which has to solve the theoretical and practical relationship in each case: I must go from thought and knowledge to action. Knowing, choosing, engaging and deciding is not enough for this; it is necessary to take one more step and feel, that is to say, relate affection, value and personal expectations so that we can achieve feeling in the form of positive relation of attachment to the value of 
what has been achieved or of what we want to achieve. The effective performance of the action requires executing through action, what is understood and interpreted, expressing it.

To make this possible we have to achieve an affective integration, as we express ourselves with the feelings that we have in each particular situation and we relate what we want to attain to specific values in an affective way (by means of positive attachment). However, we also need a cognitive integration which relates ideas and beliefs to our expectations and convictions so that we can articulate thought and believed values with reality, because through rationality, our action is based on knowledge in a explicit way. In addition, we need a creative integration, that is, we must give meaning to our acts by means of symbols, since each act which we perform requires an interpretation of the situation as a whole and in relation to the set of our actions and projects inside our cultural context: we build culture by using symbols.

We need affective habits, but the specific accomplishment of the action is not possible without the intellectual habit or without the creative, symbolising-creating, habit. In order to perform the action, the operative habit, the volitive habit and the projective habit demand the affective habit which derives from the valuefeeling relationship and generates heartfelt experience of value. We go from sensitivity to feeling and with positive attachment, we relate what we want to do to what is valuable in order to solve the situation with intellectual and creative habits.

The agents' personal qualities give character to the intervention, as a specific and singular "mise-en-scène", because people cannot stop having the values and the feelings which they have in each specific situation. This personal and singular sense puts us in a position to understand that the educational action forces to assume the value-feeling relationship and it offers us not only a theoretical and practical perspective, but also an intrinsic artistic and aesthetic perspective.

By means of feeling we express the state of mind which has been produced; depending on the fulfilment of our expectations in the action, we manifest and we expect recognition for our choice; we manifest and we expect acceptance of our voluntary commitment; we manifest and we expect reception to our projects and manifest devotion to them. Choosing, engaging, deciding and feeling a value positively has its affective manifestation in attitudes of recognition, acceptance, reception and devotion to the action. What characterises attitude is its condition of significant experience of learning born from the affective assessment of the positive or negative results in the achievement of a particular behaviour.

By means of the third condition education acquires integral, gnoseological and spiritual character. Integral character means dimensional integrated development of educatees from their internal common activity: think, feel affectively, want, choose-do (operate), decide-act (project) and create (build through symbols) in order to develop the individual, social, historical and species-being human condition with possibilities of success in the situations that may arise in all the spheres of life (personal, family, local, school, professional, etc). The integral character of education means education of educatees as a whole from their internal activity, not as a sum of all their parts. Positivity and dimensional development are principles of education derived from its integral character, since educated 
affectivity demands positivity and dimensional development as principles.

From the perspective of the integral character of education, we can say that all education is intellectual, but not everything in education is intelligence education; there are other educable dimensions of intervention which can be dealt with specifically. The same can be said about each of the other dimensions of intervention: all education is affective, but not everything in education is education of affectivity; all education is volitive, but not everything in education is education of will; all education is operative, but no everything in education is education of the capacity to act-do; all education is projective, but no everything in education is education of the capacity to decide morally; all education is creative and awareness-raising, but not everything in education is education of spirituality, significant apprehension or creativity.

From the pedagogical point of view, the integral educational action links intelligence (cognition and reasoning), affectivity and emotions (dimensioned feeling), volition (want something with determination and commitment), operation and projection (sense of action and sense of life, construction of processes and setting of goals), creation (construction of symbolised culture) of developing people and contextual variables that allow us to form a "coordinated whole" between values, thoughts, feelings, duties, choices, decisions and creations. All the dimensions take part in each case and education is not solved by dealing with only one of them.

Gnoseological character means that we are capable of cognitive integration, that is, that we learn to relate ideas and beliefs by using ways of thinking so that we can articulate thought and believed values with reality by means of knowledge and rationality in each of our choices, volitions, projects, feelings, thoughts and creative interpretations. Cognitive integration is a principle of education derived from the gnoseological character.

Spiritual character means that we generate consciousness and creativity, which makes it possible to create symbols from the human condition itself to note and signify the self, the other person and the other thing in the physical world, in the world of mental states and in the world of the contents of thought and its products. The spiritual character of education means that education is carried out in the human way and it generates mental events in educatees; we improve our self-awareness and reality awareness by means of symbols, in the human way, that is to say, as a mental corporality which integrates the mental and the physical and establishes a form of creative relationship between the self, the other person and the other thing, by means of symbols. Spiritual character means that we can build culture, that is to say, we can build by using symbols. The creative-symbolising integration is a principle of education related to the spiritual character.

For me, education is defined taking into account traits of character that determine the meaning of education. Nothing is education if it does not fulfil the conditions of common use, finality and traits of character. All educational action differs from the others because of the common use and the activity, but it is also singularised if we attend to criteria of real definition because the traits of character that determine meaning are attributed to the educational action through the objectual complexity of education. In this way, we can say that all educational action has axiological, personal, patrimonial, integral, gnoseological and spiritual character, as summarised in Chart 2. 
Chart 2: Character of the education derived from the objectual complexity of 'education'

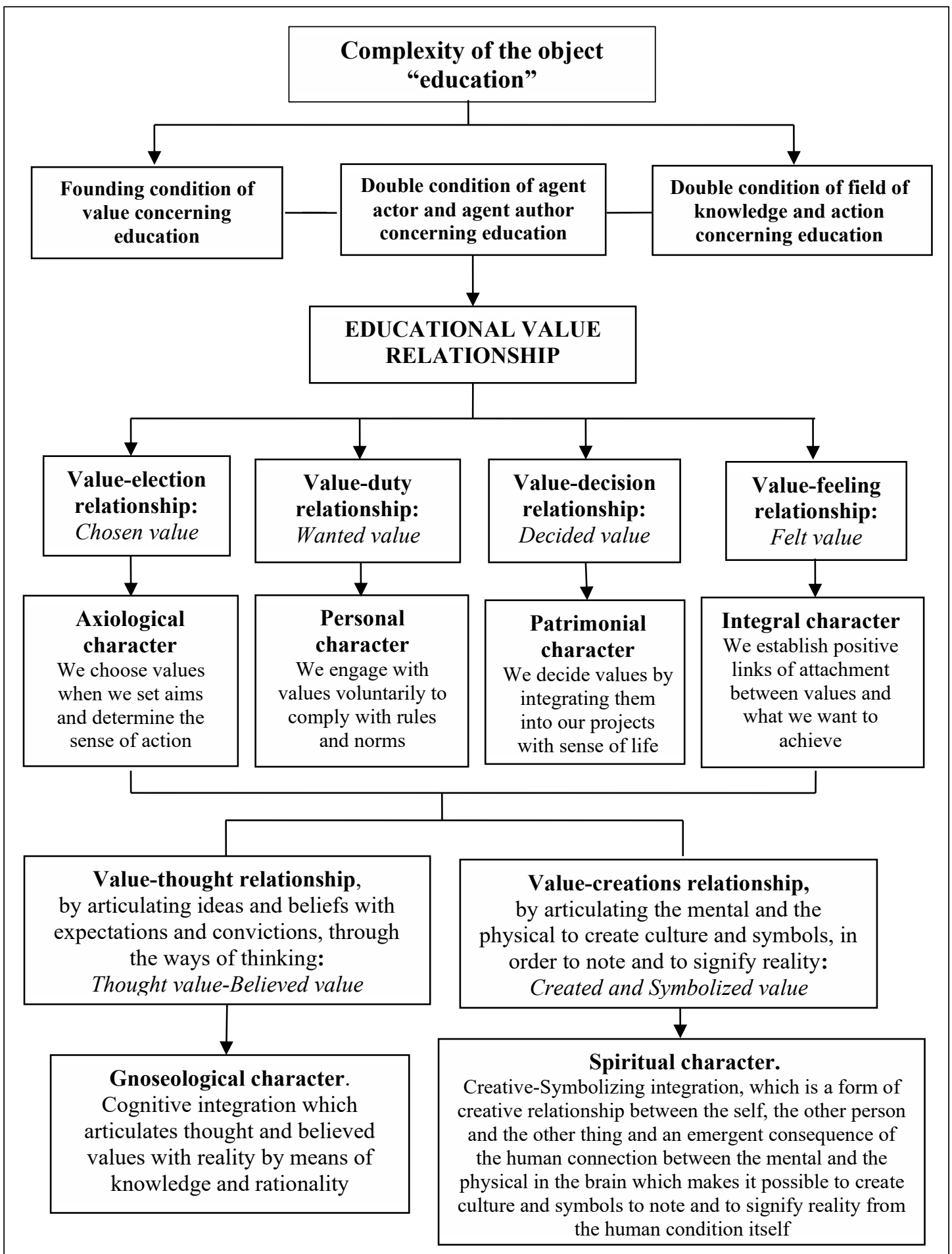

Source: Touriñán, 2014a, p. 645.

4.3. The educational relationship demands concordance between values and feelings when moving from knowledge to action
I can choose to do something, I can commit myself with that 'something' and I can even decide to integrate that 'something' as part of my projects, but then I must accomplish 
it, I must go from thought to action, I must go from attained and attainable value to effective accomplishment. This implies in each execution of action, interpretation, comprehension and expression. There is not education without affectivity, that is to say, without facing the problem of generating heartfelt experience of value. We need operative, volitive, projective, affective, cognitive, and creative habits for this. The effective accomplishment of the action requires operative, volitive and projective habits, but we also need affective, cognitive and creative habits. Only in this way we accomplish the action, which always implies to execute regarding to the comprehension, interpretation and expression (cognitive, symbolising-creating and affective integration)
By means of feeling we express the state of mind which has been produced; depending on the fulfilment of our expectations in the action, we manifest and we expect recognition for our choice; we manifest and we expect acceptance of our voluntary commitment; we manifest and we expect receiving to our projects and manifest devotion to them. Choosing, engaging, deciding and effect a value positively has its affective manifestation of linking and attachment in attitudes of recognition, acceptance, receiving and devotion to the action. What characterises attitude is its condition of significant experience of learning born from the affective assessment of the positive or negative results in the achievement of a particular behaviour. We reflect it in Chart 3 in the form of the complex relationship of valueeducatees' internal common activity, by making values and feelings concordance when moving from knowledge to action.

Chart 7: Value-feeling concordance when moving from knowledge to action

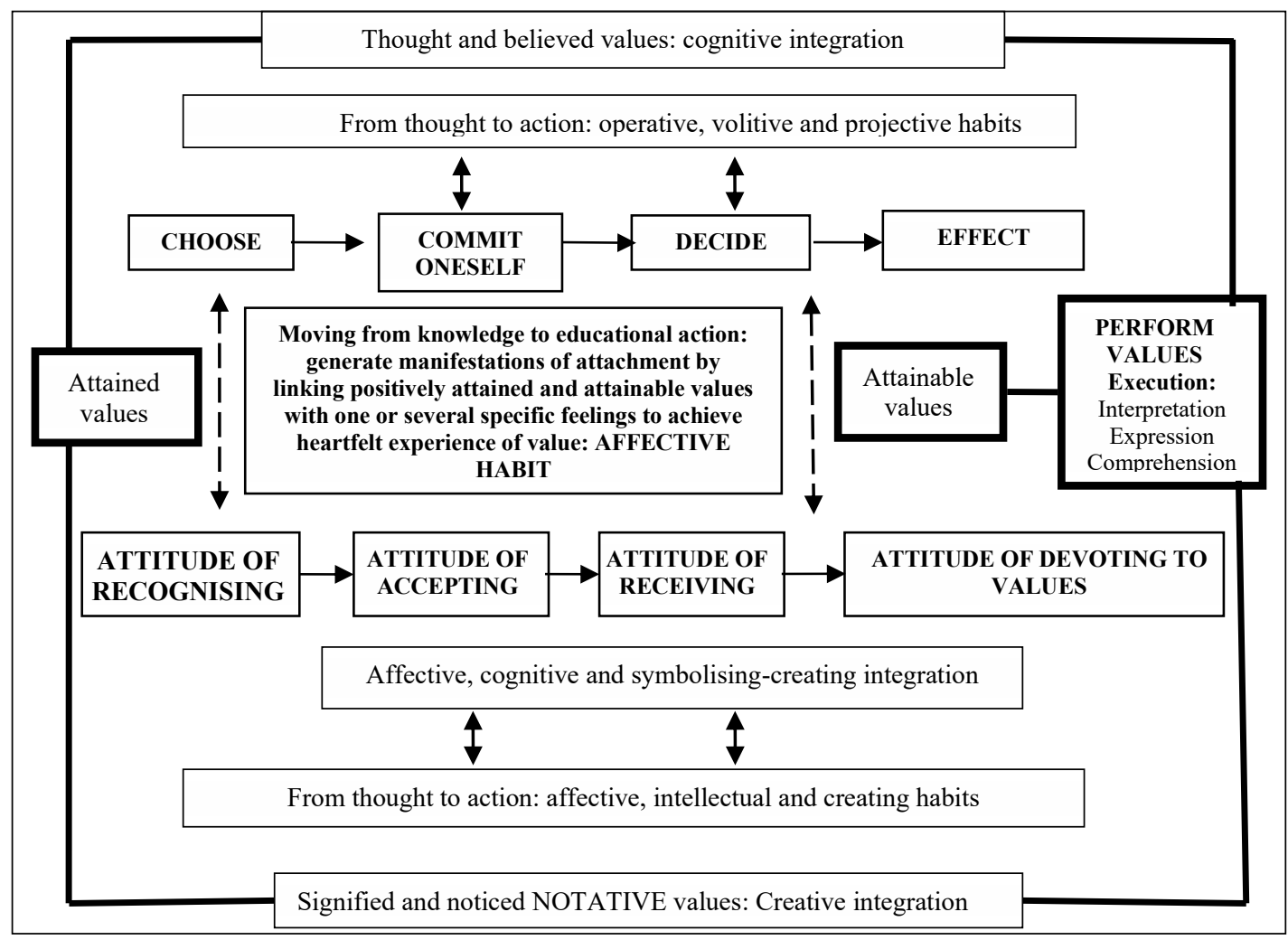

Source: Touriñán, 2014, p. 356. 
Counting on the opportunities, we reach the concrete fulfilment of a value, but we always have to make use of operative, volitive, projective, affective habits, and notative-signifying, creating habits. Whenever we carry out something we think, feel, want, choose to do, decide projects and create with symbols. Only in this way can we reach the concrete fulfilment of something, which always implies choosing processes, committing oneself (engaging voluntarily), deciding goals and projects (according to the opportunities and in each circumstance), feeling (integrating affectively, expressing), thinking (integrating cognitively, comprehending) and creating culture (integrating creatively, interpreting, by giving meaning through symbols).

Only in this way can we reach the execution of an action as an author agent, according to the opportunities and in each circumstance. The effective accomplishment of the action demands in the execution of action, interpretation, comprehension and expression. The realization requires executing through action what is understood and interpreted, expressing it. To make this possible, apart from making an affective integration (expression), we express ourselves with the feelings which we have in every concrete situation and we relate what we want to achieve to specific values affectively through positive attachment. We need to do cognitive integration (comprehension of what is thought and believed), by relating ideas and beliefs to our expectations and convictions so that we can articulate thought and believed values with reality because our action is explicitly based on knowledge through rationality. We also need to make a creative integration (symbolisingcreating interpretation), that is to say, we must give meaning to our acts by means of symbols (symbols which interpret each act), since every act that we perform requires the interpretation of the situation as a whole and in the entirety of our actions and projects within our cultural context. Creative integration articulates values and creations by relating the physical and the mental to build up culture through symbols. Creative integration articulates values and creations, linking the physical and the mental to build culture, symbolizing (Touriñán, 2019b).

If the above reasonings are correct, the double condition of knowledge and action puts us in the integral vision of the complexity of action. In order to perform the action, the operative, volitive and projective habits demand, in order to effect the action, the affective habit which derives from the value-feeling concordance in each accomplished action and generates heartfelt experience of value in its realization. However, the accomplishment of value is not possible in its concrete execution, if we do not make an affective, cognitive and creating integration in every action according to the opportunities and in each circumstance.

From the perspective of the change from knowledge to action, in every performance we follow a two-way path which allows us to go:

From choice, duty and decision to affectivity and vice versa

[? From affectivity to cognition and creativity and vice versa

[? From cognition, affectivity and creativity to aesthetics and vice versa.

Creativity and affectivity are related by means of attitudes towards innovation and heartfelt experiences of emotion and value; creativity provokes us singular feelings and feelings promote or inhibit creativity. Cognition and creativity are related by the possibility of generating a higher cognitive integration in every apprehension and comprehension of innovative reality; we use cognition and creativity to understand and interpret, signify and innovate (Novak, 1998). 
Cognition and affectivity are related because we are conscious and thinking affectivities: we relate ideas and beliefs and generate convictions about what we choose, what engages us and what we decide because we feel it, reaching in this way heartfelt experience of what is valuable, of reality, of our acts and of our thoughts. Cognition, creativity and affectivity are related to aesthetics because we are able to make symbolic interpretations and attribute meaning to beauty as harmony or relationship among forms, generating heartfelt experience of that relationship. In the articulation of action, we are able to move from sensitivity to feeling and from cognition and affectivity to creativity and aesthetics in every act.

Each case of intervention is an exercise of freedom, commitment, decision, passion and compassion; each case of pedagogical action demands to solve the concordance between values and feelings in every situation as an explicit manifestation of recognition, acceptance, reception and devotion attitudes to the educational action. However, moving from knowledge to action is not completely solved because it also demands reason and creation: every case of intervention is a "miseen-scène" whose realization implies, according to the opportunities and in each circumstance, execution, interpretation, comprehension and expression, which also demand affective integration, cognitive integration and symbolising-creating integration.

Each performance is a path which implies thought and believed value, created, symbolised and signified value, chosen value, committed value, decided value and felt value. Moving from knowledge to action settles us in the complexity of the attained value, the attainable value and the attainment of value. The educational relationship acquires axiological, personal and patrimonial character and also integral, gnoseological and spiritual character.
Within the framework I have just described, I would like to talk in this article about the educational relationship as a concrete act. Not as a question of educability which would lead us to enumerate the human capacities which make it possible to receive education, or as a question of educativity which would lead us to enumerate competences which make it viable for a subject to be able to give education. Obviously, it is not a question of formal and real freedoms which guarantee the opportunity to educate in a legally determined territory which constitutes the institutional form to approach the relationship between justice and care. I want to deliberate on the concept of "educational relationship" which joins educability, educativity and opportunity to educate in an only act and I want to deliberate on that concept by cultivating an independent reflection, as Herbart would say. The result of my thoughts about that question is what I intend to offer. My supposition is as it follows (Touriñán, 2016, 2017a):

Educational relationship is the substantive form of educational intervention; it is its concrete act. It is identified with the interaction which we establish to perform the activity of educating and, precisely for this reason, it may be seen as the set of cares which we do to educate. It is interaction of identities for educating.

In the educational relationship we strengthen the ability to make the action of educating and our knowledge of it compatible, in order to answer the question what activities count to educate and what counts in the educational activities in every concrete educative action. To achieve this, we have to choose and value according to the knowledge which we have about the educational action, since 'education' has a meaning of its own.

Therefore, I see educational relationship as the exercise of education and it implies assuming the complexity of education, which I have 
systematised in a triple conditional axis: values, actor and author agent and the concurrence of knowledge and action. This triple condition must be fulfilled in each concrete case of the educational relationship because complexity establishes the traits that determine the meaning of "educational", which allow singularising the relationship with respect to other types of relationships. If those traits of meaning which characterise 'education' are not fulfilled, the educational relationship will be generically relationship, but it will not be able to be specifically educational because it would not manage to be characterised against other relationships. We must assume that in educational relationship:

- In educational relationship, a connection between value and choice is created in such a way that we can improve the responsible sense of action, in accordance with the axiological character of education, building processes from the means-ends relationship

- In educational relationship, a connection between value and duty is created in such a way that we can improve the voluntary commitment of action, in accordance with the personal character of education

- In educational relationship, a connection between value and decision is created in such a way that we can improve the individualised sense of life which that action has, in accordance with the patrimonial character of education, building goals

- In educational relationship, a connection of attachment or dependence is created between value and feeling in such a way that we can orient ourselves towards the achievement of heartfelt experience of value by means of affective integration, in accordance to the integral character of education

- In educational relationship, a connection between ideas and beliefs with expectations and convictions is created by means of ways of thinking, in such a way that we are able to integrate thought and believed values with reality cognitively, in accordance to the gnoseological character of education

- In educational relationship, due to the human relationship of the mental and the physical, a connection between signs and meanings is created in such a way that we are able to make a symbolising-creating integration of value and give it meaning, in accordance to the spiritual character of education; we are able to symbolise, building culture

- $\quad$ And finally, as I am going to explain in the following section, in educational relationship, a connection is created between categories of space-time-gender-specific difference, regarding the relationship between the self, the other person and the other thing in each educational act, so that we are able to maintain in each intervention the territorial, lasting, cultural and formative meaning of education.

Each of these links are demands, by principle of meaning, to educate: nothing is educational if it does not have the proper character and sense traits which are inherent to the meaning of education; only then will the relationship be educational. The educational relationship is, therefore, interaction to educate and this implies assuming the complexity of education itself, and the demands derived from the characteristics of the meaning of educating, which must be manifested, in each intervention through common activity (Touriñán, 2016).

We intervene to establish an educational relationship that manages to educate and for this we use the activity of the educatee and the educator. The educational relationship is the focus of the function of educating in which the interaction between myself, the other person and the other thing takes place. And precisely for this reason, from the perspective of the educational 
relationship, the interaction of identities (the relationship with the other) is a defining component in education. Regarding ourselves and others, in the self and hetero-education processes, we have to achieve in the educational relationship the passage from knowledge to action and this requires achieving a staging in which the values-feelings concordance occurs: Choosing, committing, deciding and carrying out must have their concordance in concrete action in attitudes of recognition, acceptance, receiving and devoting to the task and to the achievement, respectively.

In educational relationship, therefore, we look for values-feelings concordance in each interaction and for this we choose, commit ourselves, decide and carry out what is decided. And to effect, we execute through action what is understood and interpreted, expressing it. Accomplishment requires executing by means of action. And that action, in addition to the internal common activity of the subject, always uses the external common activity of the educatee. We carry out through play, work, study, inquiryexploration, through intervention in each act and through the relationship established between the self and the things we use in each interaction, which is always defined as a relationship the self-the other person-the other things. And all this is made by the educator in the educational relationship. Let's see the pedagogical sense of education in more detail below.

5. THE SENSE OF EDUCATION AS A RELATIONSHIP BETWEEN THE SELF, THE OTHER PERSON AND THE OTHER THING IN EACH EDUCATIONAL ACT, ATTENDING TO

\section{CATEGORIES WHICH QUALIFY ITS MEANING}

In educational relationship we always act with a specific perspective of approach or qualification, which is inferred from the relationship which is established between the self and the other person in each educational act attending to the qualifying conceptual categories of space, time, genre and specific difference; that is to say, we appeal to the sense of education properly. The sense of education is what qualifies it. The agents act and their actions have sense of action (means-aims relationship) and sense of life (decision-projects-goals relationship), but they also have the proper sense of the meaning of the action which we carry out: a sense which is inherent in the meaning of 'education' corresponds to the educational action (Touriñán, 2013a). The meaning of education is established by the traits of character and sense. Character determines the meaning of 'education'; sense, derived from the relationships between the agents in each educational act, qualifies the meaning of 'education'.

The character of education arises from the objectual complexity of education. As we have just seen in the previous epigraph, it is possible to systematise the complexity of the object education from three axes that determine the traits of character of education: the founding condition of values in education, the double condition of agent-author and agent-actor of each subject concerning their education and the double condition of field of knowledge and field of action for education. Nowadays the character of education is established as an axiological, personal, patrimonial, integral, gnoseological and spiritual character (Touriñán, 2016).

The sense of education arises from the relationship that is established between the self, the other person and the other thing in each educational act. In each specific situation we perform and are conscious of things and of ourselves and generate symbols which give 
meaning to the self, the other person and the other thing and allow the interpretation, transformation and comprehension of reality and the creation of new forms and culture. Thanks to this possibility to create symbols in order to note and to signify culture and reality from our own human condition, we can speak about the individual, social, historical and species-being human condition, because man adapts, accommodates and assimilates his condition from a symbolised world. Our creative and symbolising habits allow us to interpret the relationship between the self, the other person and the other thing in each case (Touriñán, 2014a; Touriñán, Dir, 2012).

The relationship between the self, the other person and the other thing is a type of relationship that requires to combine identity, territoriality and the interrogative horizon of reality and existence in the formative development of the human condition, by articulating the limits of the singularly personal, the environmentally close and the universal in each action, three categories related to the "self", "the other person", and "the other thing" in each specific case of performance (Touriñán, 2015). The sense of education is established nowadays through the relationship between the self, the other person and the other thing in each educational act attending to the conceptual categories of space, time, genre and specific difference, as a spatial (territorialised), temporary (durable), genre (cultural) and specific difference (formative) sense. From the point of view of the sense of education, all educational action is described as having territorial, durable, cultural and formative sense and it admits varied answers, attending to the circumstances of each case (Touriñán, 2016).

The sense of education is a fundamental element in the meaning of education, not only because the relationship of the self, the other person and the other thing is qualified in each action attending to the conceptual categories of space, time, genre and specific difference, but because we will not understand the condition of educational agent in its extent if we don't combine identity, territoriality, and the interrogative horizon of reality and existence in each action: my right 'to' and 'of' education is a legal right and legitimately integrated within a territorial legal framework and with some specific circumstances that condition specific opportunities. If we do not respect the limits of the singularly personal, the environmentally close and the universal, the agents lose their position as subjects situated in the world. Without that caution, we will not distinguish between the territorial integration of cultural differences and the transnational inclusion of cultural diversity in each educational agent.

\subsection{The Sense of Education Is Inferred from the Relationship between the Self, the Other Person and the Other Thing in Each Educational Act and Qualifies the Meaning of the Term Attending to the Conceptual Classifying Categories of Space, Time, Genre and Specific Difference}

In pedagogical debate we speak about intellectual, affective, volitive, operativeintentional, projective-moral, and creative education. We also speak about rhythmical, verbal, linguistic, mathematical, and audiovisualvirtual education. We also speak about religious, environmental, scientific, and natural, and sociohistorical education. Each of these three ways of speaking reflects particularly a different way to tackle education: in the first case, we speak about pedagogy of the general dimensions of intervention; in the second case we speak about pedagogy of the forms of expression and in the third case we speak about pedagogy of the areas of experience. The forms of expression and experience constitute fields of education and are susceptible of pedagogical intervention. Each of these fields can be developed attending 
to the general dimensions of intervention, from a specific perspective of orientation or qualifying purpose. Education can have diverse philosophical senses: it can be humanist, localist, globalist, nationalist, communitarianist, assimilationist, multiculturalist, interculturalist, intellectualist, relativist, secularist, and so on (Carr, 2014). However, when we speak about sense as a feature of the meaning of education, we want to refer to an inherent qualification in the meaning of education, connected with the relationship between the self, the other person and the other thing in each educational act, attending to the classifying categories of space, time, genre and specific difference. From this perspective, any educational action, whether it is humanist, socialist, etc., will have a territorial, durable, cultural and formative sense; it will have the sense inherent in the meaning of education.

When we talk about cultural sense, for example, we are not talking about a general dimension of intervention, nor about one of the fields of education (they are the result of valuing the area of cultural experience as 'education'), nor about one of the philosophical senses attributable to education from the perspective of the aims. When we talk about cultural sense, we are thinking about a qualifying trait which is characteristic of the meaning of education and which integrates into the temporary formative orientation for the individual, social, historical and species-being human condition. All education has a cultural, territorial, durable and formative sense because of its meaning.

In open, pluralist and constitutionally nonconfessional societies, it is obvious the need for models of intervention which favour the cultural sense as a defining trait which is inherent in the meaning of education. This admits several answers, from multiculturalism to interculturalism, from the symmetric to the asymmetric treatment of differences, from the territorial integration of differences to the transnational inclusion of diversity, but always in line with the traits of character and sense inherent in the meaning of education. The cultural sense of education is related to the educational principle of diversity and difference, as it is a defining trait which qualifies the meaning of education, attending to the conceptual classifying category of 'genre'.

The sense of education is related to the formative answer which is given to the individual, social, historical and species-being human condition in each cultural moment. The sense of education integrates into the temporary formative orientation of the human condition by means of the school subjects, but it is not mistaken with the school subjects, derived from the cultural areas which are valid and consolidated in every socio-historical moment. For this reason it makes sense to say that all education has to be personal (which is a trait which determines meaning and derives from the objectual complexity of 'education'), but not all education is necessarily about mathematics, physics, literature or arts. At the same time, if we attend to the relationships which are established between the self, the other person and the other thing in each educational act, it makes sense to say that all mathematical, physical, artistic or literary education has to be thought as education with a territorial, durable, cultural and formative sense. And taking into account the conceptual and classifying category of "genre", that pedagogical sense admits different specific answers depending on whether it is a general or professional school subject, of occasional, permanent or continuing education, of traditional classroom instruction or virtual education, of synchronous or asynchronous education, et cetera.

Pedagogical sense of education comes from the relationship which is established between the self, the other person and the other thing in each educational act, attending to the conceptual categories of space, time, genre and specific difference which are present in the meaning 
of education. It is a type of relationship that requires to combine identity, territoriality and the interrogative horizon of reality and existence in the formative development of the human condition by articulating in each action the limits of the singularly personal, the environmentally close and the universal, three categories related to the "self", "the other person", and "the other thing" in each specific case of performance (Touriñán, 2015 y 2013b).

According to the knowledge of education, the character and sense of education are the two elements that integrate the meaning of 'education'; character determines meaning; sense qualifies it. From this perspective, education is regarded as a task and as an achievement oriented to develop valuable experience and to achieve the use of more suitable forms of expression so as to print on education and on every pedagogical intervention, the character that determines the meaning of education from its objectual complexity (axiological, integral, personal, patrimonial, gnoseological and spiritual) and the sense that qualifies the meaning of education, from the relationship which is established between the self, the other person and the other thing in each educational act, attending to the conceptual categories of space, time, genre and specific difference (territorial, durable, cultural and formative). The self, as an individualised singularity, has to educate itself in all the traits of character inherent in the meaning of education. The self, relating to the other and the other thing, has to educate itself in the traits of sense inherent in the meaning of education and give an appropriate answer according to the specific opportunities and the particular circumstances of each action (Touriñán, 2014a).

In each educational act there is a connection between the self, the other person and the other thing and the sense of spatial, temporary, genre and specific difference qualification is generated in education. A territorial, temporary, cultural and formative sense is materialised in each educational act, without which education is not defined. All education has a spatial (territorial), temporary (durable), genre (cultural) and specific difference (formative) sense, regardless of the area of cultural experience with which we educate and regardless of the philosophical sense which a society attributes to education (Touriñán, 2014b y 2015).

The durable, territorial, cultural and formative sense qualifies the educational action in each specific case according to the opportunities. Sense does not only determine the meaning of education. Attending to these four conceptual classifying categories, the relationship between the self, the other person and the other thing in each specific case allows us to speak about permanent and occasional education, about traditional classroom instruction and distance learning, about synchronous or asynchronous education, about virtual education, about local, global and glocal education, about multicultural and intercultural education, about vocational, general and professional education, etc.

In each educational act we combine identity, territoriality and the interrogative horizon of reality and existence to respect the limits of the singularly personal, the environmentally close and the universal, as summarised in Chart 3. 
Chart 3: Sense of the education derived from the connection established between the self, the other person and the other thing in each educational act and which qualifies meaning from the conceptual categories of space, time, genre and specific difference

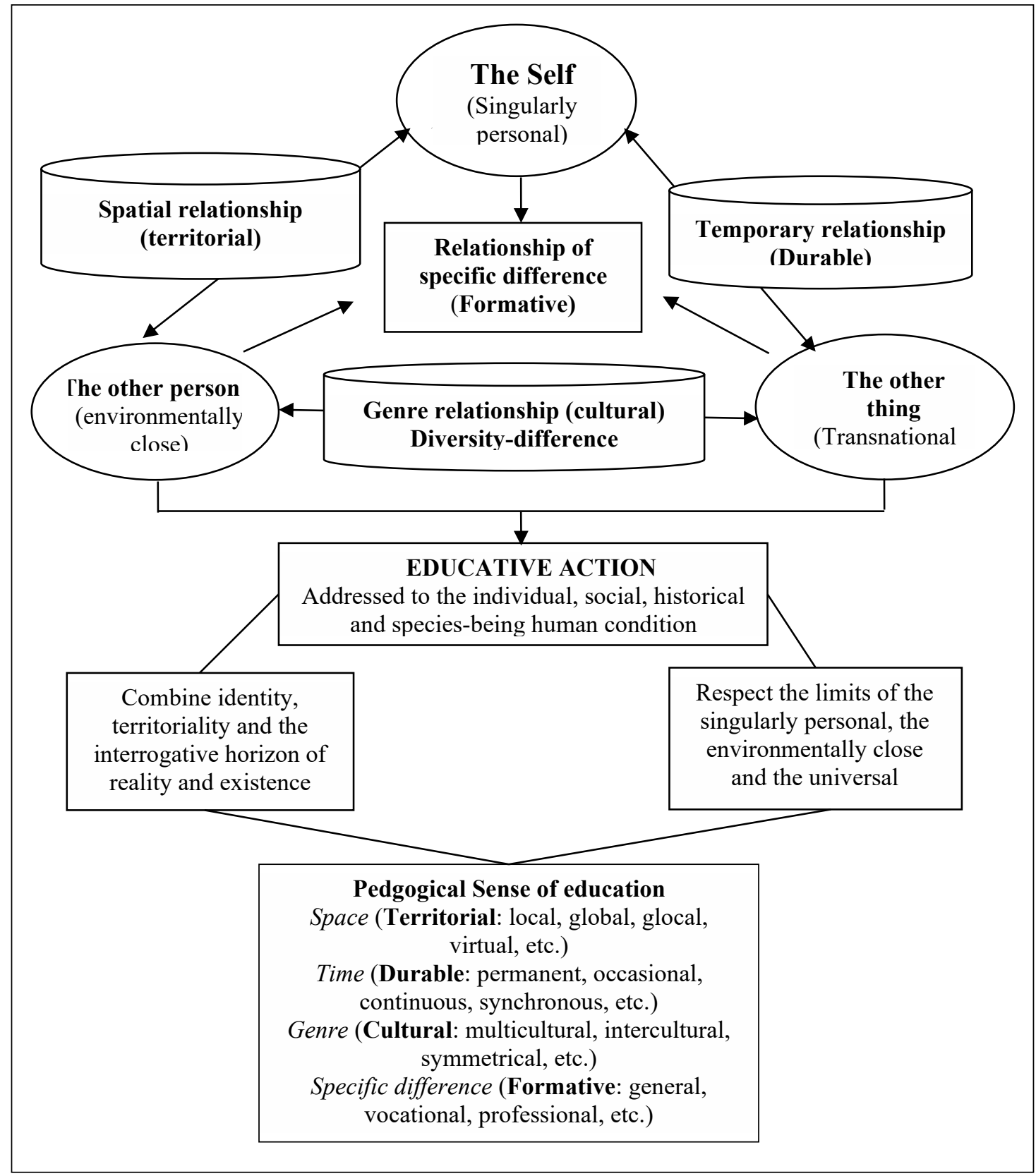

Source: Touriñán, 2014, p. 500.

There is a connection between the self, the other person and the other thing in each educational act, therefore the territorial, durable, cultural and formative sense is generated in education attending to the conceptual classifying categories of space, time, genre and specific difference. Through the relationships between the self, the other person and the other thing, we combine identity, territoriality and the interrogative horizon of reality and existence in each educational act and, through the relationships themselves, we respect the limits of the singularly personal, the environmentally close and the universal in each action. A territorial, durable, cultural, 
and formative sense is materialised in each educational act, and education is not properly defined without it. All education has a temporary, territorial, cultural sense and it is specifically formative. The sense of cultural diversity, either permanent or not, glocal or not and of vocational formation or not, qualifies education in a specific cultural and territorial framework. Sense does not only determine the meaning of education; it qualifies it and this qualification has territorial conditioning integrated into each temporary formative orientation. Neither everything in the education of diversity is fusion nor cultural integration, for example, nor all education is education if it favours fusion or integration, because diversity is not only respected through fusion or integration. That is to say, there will always be an answer which marks the sense of education in relation to the conceptual category "genre", because all education has a cultural sense, but the educational answer to the cultural sense of diversity is not only one, because the answers of symmetric and asymmetric treatment of the differences are equally real and possible. This way of reasoning is applied to each performance of sense: neither there is only an answer of educational sense to cultural diversity, nor there is an only type of educational answer to educational sense derived from the conceptual category "space"; however, the answer has a territorial sense depending on the cases, since it is global, local or glocal, and so on and so forth:

- There is always a relationship of coexistence between the self and the other person and the other thing as an interaction of identities in a territorial framework. The basic principle of coexistence is territorialized socialisation and precisely for this reason it is a principle of education related to its sense. From the conceptual category "space", the sense of education is nowadays territorial. In a territorial sense, education does not have to be either of a localist, or a globalist nature, it can also be glocal; in certain cases, I can go from local to global and vice versa, from global to local. There is not an only answer, it is not only about thinking locally in order to act globally and make everybody in the image of "my national location", or about thinking globally so as to act locally and make everybody in the image of a uniform world without identity roots and culturally diverse. Taking into account the conceptual category of space and from the perspective of the relationship between the self and the other person, the sense of education is territorial, and it does not have to be considered in only one direction. Education has a sense of spatial qualification (territorial sense: sometimes glocal, sometimes local, sometimes global, sometimes planetary, virtual, face-to-face, et cetera).

- $\quad$ There is always a temporary relationship between the self and the other thing and the other person, because reality is inexhaustible, and we have to interpret it in each action. Time, as well as space, is related to the educational action in the form of durability or duration, since the activity of learning and education, whether formal or activity about free time, goes beyond the school period and the formal processes of school intervention; the progressive improvement is possible along people's life and that is the reason why improvement and progressiveness are principles of education related to its sense. Progressiveness is related to personal past experience by means of life experience; progressive improvement acquires a different meaning and assessment in each stage of human development (childhoodadolescence-youth-maturity-old age); a different meaning according to personal experience. We keep memories of past experiences belonging to different stages of life, time is not lived with the same intensity in each moment. Attending to the conceptual category of time and from the perspective of the relationship between the self and all the other things, the sense of education is durable: permanent, continuous and, occasional, etc., depending on the case. In education there 
is a sense of temporary qualification (sense of duration: sometimes permanent, sometimes occasional, sometimes continuous, sometimes synchronous, diachronic, asynchronous, et cetera).

- $\quad$ From the self's perspective there is always a cultural relationship between the other person and the other thing: all educational action is culture and it is diverse and different, because the self differs from everything else and educates itself by means of cultural symbols. The sense of education is cultural from the perspective of the relationship with the other person and the other thing and attending to the conceptual category of genre. It is a relationship marked by the educational principle of diversity and difference, because each one is the way they are and each thing is what it is, although they can be changed in the interaction. We look for diversity and difference without turning them into inequality. Precisely for this reason diversity and difference are principles of education related to its sense. Within "education" as a whole, the cultural sense of education must be understood as the use and construction of axiological experience about the diversity and the difference which the other person and the other thing represent in order to build oneself and recognise oneself with the other person and the other thing in a diverse cultural environment of interaction by means of the values which we must choose, engage with, decide and perform. Assuming this principle of qualification and sense of education demands common goals and harmonic feasibility between men and cultures. In education there is always a cultural sense of qualification of genre (sometimes, with an intercultural answer; sometimes with a multicultural answer; sometimes with an answer of symmetric treatment of differences; sometimes with an answer of asymmetric treatment of differences; etc.). It is always a cultural sense which acquires different answers in the temporary formative orientation, concerning diversity and difference
- There is always a relationship of formation between the self, the other person and the other thing which affects the human condition in a general, vocational or professional way. Any cultural area can be an instrument to develop in educatees values related to the theoretical, technological and practical mastery of the area as a creative expression which can be known, taught, investigated and performed. However, the area is not only an instrument of professional education. We can know a cultural area, we can teach an area and we can educate "with" the cultural area, whether to develop the inherent character and sense in the meaning of education in educatees, or to develop the conceptual sense of the area within each educatee's general formation, or to contribute to form specialists in the cultural area from a vocational or professional perspective. Attending to the conceptual category of specific difference and from the perspective of the relationship between the self, the other person and the other thing, the sense of education is formative; all educational action is formative, otherwise it is not education. Nevertheless, there is not an only formative answer; it can be general, vocational and professional formation. It is always a sense of formation based on interest. Nobody is forced to go beyond their interest in their formation when thinking about their profession and vocation, and nobody is forced to attain everything in their general formation, because each educatee has a limit in the ability to show interest in any subject. Formation and interest are principles of education related to its sense. In education there is always a sense of qualification of the specific difference (sometimes a sense of general formation; sometimes vocational; sometimes professional, et cetera).

\section{THE MEANING OF 'EDUCATION' AS A CONFLUENCE OF DEFINITION CRITERIA}

Through the knowledge of education, character and sense of education are the two elements 
which integrate meaning from the perspective of the real definition of 'education'; character determines meaning, sense qualifies it. The classic concept of nature of education is identified with the concept of character which I am using. However, in a broad sense, that of the way things are or act once they have been produced or born, the concept of nature of education involves character and sense, inherent in the meaning of "education", which cannot be confused with the school subjects derived from the valid and consolidated cultural areas in each historical moment.

The real meaning of education is a confluence of character and sense. Character is the distinctive trait or set of characteristics which determine something as what it is. The character of education is its determination, what determines it. The sense of education is what qualifies it; it is the specific perspective of approach or qualification, which is inferred from the relationship which is established between the self, the other person and the other thing in each educational act, attending to the conceptual classifying categories of space, time, genre and specific difference.

From the perspective of the real definition, any act of educational meaning has to be done according to the determinations and qualifications which correspond to the real meaning of education. All education has to adjust to character and sense. Mathematical education, chemical education, physical education, literary education, artistic education, moral education, civic education, et cetera are education because they primarily fulfil the conditions of character and sense characteristic of the meaning of "education", but not all education has to be mathematical in order to be education.

It makes sense to say that all education has to be personal (which is a determining trait of character derived from the objectual complexity of 'education'), but it is not necessarily about mathematics, physics, literature or arts. At the same time, it makes sense to say that all mathematical, physical, artistic or literary education has to be considered as education with a territorial, temporary, cultural and formative sense, attending to the relationships established between the self, the other person and the other thing in each educational act.

In this way, the meaning of education is shown as a confluence of character and sense in each intervention, as real definition. In addition, the set of conditions derived from the criteria of use and final activity which complete the definition from the nominal point of view appear in each intervention. Thus, the meaning of 'education' demands the confluence of nominal and real definition, so that it may adjust each activity to the criteria of use, finality and traits of character and sense which are characteristic of the term 'education', as we reflect in Chart 4. 
Chart 4: Meaning of education as a confluence of definition criteria

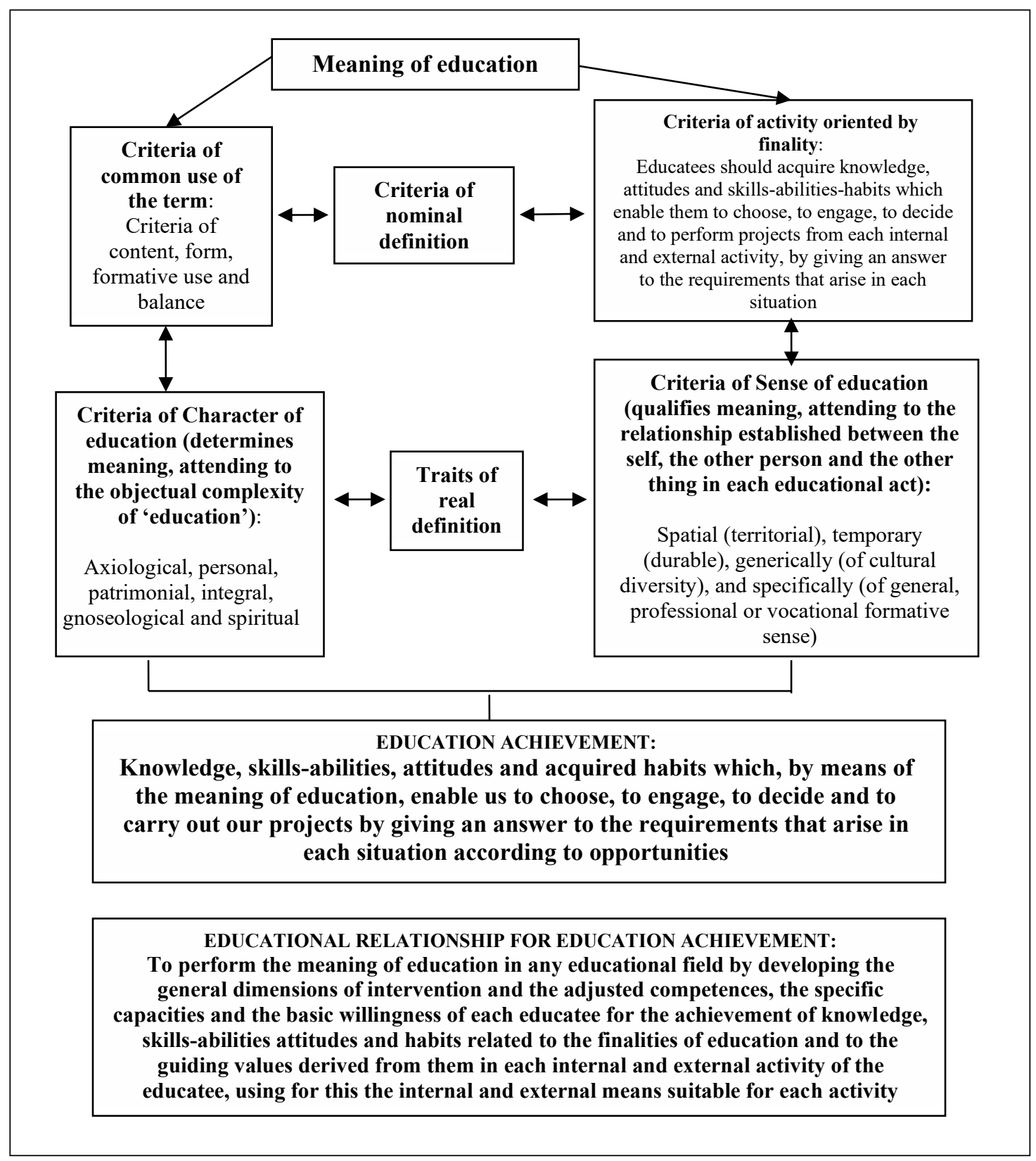

Source: Touriñán, 2014, p. 651. 
Attending to the nominal and real definition, we can say that educating is, as an activity, a specified activity; it is not any activity, although any activity can be changed into an educational activity if we manage to make it fulfil the criteria of common use, finality and real meaning. In order to be so, the educational activity, requires the fulfilment of the conditions of character of education (axiological, personal, patrimonial, integral, gnoseological and spiritual) and the conditions of sense of education (territorial, durable, of cultural diversity and specifically formative with a general, professional and vocational sense), as well as the criteria of use and finality.

\section{THE CONCEPT OF 'EDUCATION'} AS A CONFLUENCE OF MEANING AND TEMPORARY FORMATIVE ORIENTATION IN EACH INTERVENTION, regarding internal and external COMMON ACTIVITY

From the point of view of the knowledge of education, it is useful to distinguish two types of aims on education (aims):

- Intrinsic aims, because they are decided in the system and their content is knowledge of education in the sense of the technical decisions

- $\quad$ Extrinsic aims, because, although they are decided in the system with the help of the valuable knowledge of education, their content is sociocultural and praxically legitimised as good for education in a particular socio historical place and moment, in the sense of praxical (moral and political) decisions.

Both types of aims are subject to historical character. However, their origin is different because of the type of discourse which justifies it. On the one hand, we say that man has to express himself historically and literarily, for example, to be educated at this time (extrinsic finality) and on the other hand, we say that it is necessary to develop a critical sense, because man will not be able to educate himself without it (intrinsic finality, typical of the educatee's internal activity identified as "thinking"). In the first case, man will be more or less educated, depending on the areas in which he expresses himself. In the second case, man will not have education, if he does not have a formed critical sense, since criterion and rationality are features of logical need with regard to the concept 'education', which are related to the character of education.

It seems reasonable to affirm that a way to distinguish intrinsic aims from extrinsic aims consists in distinguishing "logical need for something" (What makes something be education?, -criteria and features of meaning which determine and qualify as education-) and 'sociocultural expectations addressed to the system education' which express what society expects from education. Logical need and expectation integrate into the 'temporary formative orientation of the human condition', which is individual, social, historical and speciesbeing, in a particular moment (who is the educated man at each time?). In both cases we must base our decision of determining aims by appealing to the meaning of education (Touriñán, 2015, 2014c).

Thus, once again it is confirmed in this discourse that theoretical, technological and praxical knowledge (about literature, history, philosophy, life experience, morality, habits, etc.,) of the diverse cultural areas which become an aim of knowledge in education is not created by the professionals of education with their specialised knowledge (knowledge of education). These types of knowledge are created by the specialists of each of those areas and they can be turned into goals, which are socially and morally legitimised in that society. For this reason, they are good candidates to become an educational goal. If, in addition to being socially and morally legitimised, they are elected because they are justified through the criteria and typical traits of 
the meaning of 'education', they do not become candidates for an educational goal, but an effective extrinsic finality (Touriñán, 2019d y 2019e).

For their part, intrinsic aims are those which are decided in the system and their content is knowledge of education. The validity of their principles does not only come from their socially and morally desirable character, or from their validity in a cultural area, but from the specific proofs of the field, that is to say, from the meaning which is attributed to these principles from the conceptual system elaborated with the knowledge of education.

We can say that intrinsic finalities (aims) are frequently known as pedagogical goals, which are aims related to the educational project and arise from the knowledge of education. Extrinsic finalities (aims) are generically known -in the absence of a more specific name- as educational goals. The former aims are related to what is inherent in the criteria of meaning which make it possible for something to be 'education' and not another thing; the latter are related to the socio historical orientation of education, that is, with what society expects from education. Both types of finalities are integrated into the orientation of the temporary formative answer for the human condition in each period, without contradicting the meaning of education (Touriñán, 2013b).

The temporary formative orientation for the human condition is the educational model or pattern of that society (the type of people who we want to make with the formation which we give them in a specific historical moment). By means of intervention, we turn the knowledge of cultural areas into education in each field of education that we build.

The temporary formative orientation integrates the content of education and it allows defining and differentiating the educational answer related to the central and complementary questions of the concept of education in each territory, in relation to the changeable and the permanent, the essential and the existential, the structural and the functional, what corresponds to the being or the becoming of education in each specific socio historical moment and which is reflected in the curricular architecture and in the fields of education which we build, as shown in Chart 5. 
Chart 5: Concept of education as a confluence of meaning and temporary formative orientation

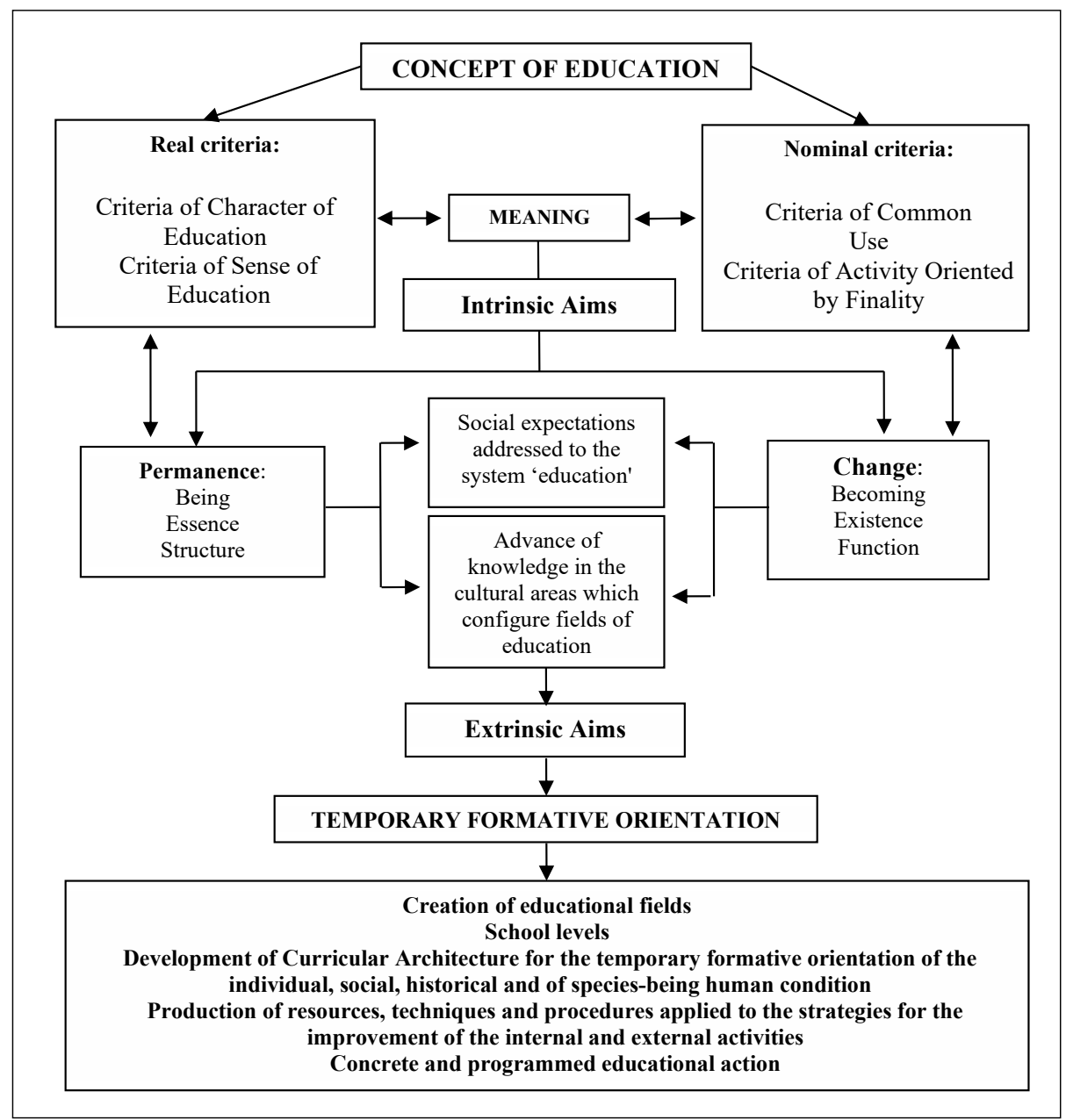

Source: Touriñán, 2014a, p. 653.

All temporary formative orientation combines tradition and innovation, personal cultivation and commitment with greatness of purposes, because that is the framework in which the educational aims which arise from the social expectations addressed to the system move. Tradition and innovation (sometimes hidden under the terms of modernity and progress) are combined, not on an impulse by the politician of the moment, but because, by assuming the character of shared responsibility in education, everybody admits that, when defining the human that we want to educate, neither everything in tradition is rejectable, nor only innovations respond to the knowledge which has to be preserved. Personal cultivation and greatness of purposes are combined because education, understood in its full sense, does not reach its aim by developing a man who is able to manage on his own and for himself. Besides, it has to be understood that this personal core will not be achieved unless education safeguards and cultivates the sense of the relationship with the other person and the other thing in each educatee, that is, the social sense of diversity and identity in coexistence spaces. This implies trying to assume the commitment with the main rights and duties which we, as citizens and as members of the community, have to fulfil in the legal territorialized framework. Temporary formative orientation responds to the meaning of education and to the social expectations 
addressed to the system in the form of fulfilment of the functions which are attributed to it, since education is a factor of social development.

The different ways to tackle education, from the perspective of pedagogical knowledge, always allow speaking about it as a chosen value with an educational finality. From the point of view of the intervention, education is committed to extrinsic finalities or educational goals and to intrinsic finalities or pedagogical goals so as to attain the fulfilment of the logical demands of the meaning of education which determine and qualify skills, habits, attitudes, knowledge and competences as components of educational value recognised to build oneself, in other words, to educate oneself.

Temporary formative orientation is made through the singularity of situations, through the generated educational knowledge, through the advance in cultural areas and through the pertinence and relevance of the values which are valid in a particular society. School subjects are grouped in the curricular architecture according to the levels of the educational system and respecting the criteria and traits of the nominal and real definition of education. The temporary formative orientation for the human condition offers the pattern, that is, the educational model in each specific society, in the framework of identity, diversity and territoriality by means of cultural areas which are valid, consolidated and transformed into fields of education.

Formative orientation is applied by means of school subjects, and it lives on strata of thought, derived from diverse cultural areas and varied condition, which go from humanism to communitarianism, from nationalism to individualism, from ethics to aesthetics, from morality to religion, from philosophy to science, from anthropology to culture and so on and so forth. Education is not mistaken, or identified with these strata necessarily, because its meaning is specific, different and characteristic of that sphere of reality which is education and it is also adjusted to the nominal and real definition. Education will have temporary formative orientation in the educational politics of a socialist, humanist, communitarianist, secular, confessional, nonconfessional, etc., profile depending on the historical moment and attending to the greater or lower preponderance of a particular type of civic mentality; these are the philosophical senses of education related to social expectations (Pring, 2014). Besides, in all those cases education is education substantively and thus it keeps -it has to keep, at the risk of losing its own conditioncoherence with the meaning of education, with the features of character and sense which are inherent in the meaning of 'education'. In this way, education will be able to be socialist, humanist, etc., but it will only be necessarily education if it fulfils the conditions of character and sense of meaning: all education is education, because it has axiological, personal, patrimonial, integral, gnoseological and spiritual character and because it has a territorial, durable, cultural and formative sense in each of its actions. In this way educational action will not stop being education and it will not become a propaganda channel of the political ideas of the dominant group (Touriñán, 2017a y 2020a; Touriñán y Longueira, 2018).

This is because education is a process of maturing and learning which involves achieving the meaning of education in any educational field, by developing the general dimensions of intervention and the adjusted competences, the fundamental habits of development, the specific capacities and the basic disposals of each educatee for the attainment of the aims of education and the guiding values derived from them. For this reason, we can say that education is use and construction of axiological experience to choose, engage, decide and perform a personal life project by responding to the demands which arise in each situation in accordance with opportunities. In short, it is 
an activity oriented to build oneself and identify oneself with the other person and the other thing in a diverse cultural environment of interaction, by means of the values which we have to choose, engage with, decide and carry out.

In educational relationship, as we have said, we look for values-feelings concordance in each interaction and for this we choose, commit ourselves, decide and carry out what it has been decided. And for effecting, we execute through action what is understood and interpreted, expressing it. Accomplishment requires executing by means of action. And that action, in addition to the internal common activity of the subject, always uses the external common activity of the educatee. We carry out through play, work, study, inquiry-exploration, through intervention in each act and through the relationship established between the self and the things used in each interaction, which is always defined as a relationship the self-the other person-the other things. And all this is regarded by the educator in the educational relationship as means for action.

Finally, as we have explained in the section dedicated to the pedagogical function, we educate ourselves with internal common activity. But, in addition, we educate ourselves through external common activity (studying, playing, working, inquiring-exploring, intervening and relating to the self, the other person and the other thing), because by exercising a specific external common activity we activate the internal common capacities, we train them, we exercise them, we drill them and we improve them to do well each external common activity. The external common activity, by principle of activity, activates the internal common activity in each specific execution of the external common activity, whatever it may be (playing, studying, working, inquiring, intervening or relating). By executing the external common activity, we improve and train the internal activities-capacities: without the activity it is impossible to educate and through the activity it becomes possible for the educatee to be an actor-agent and an increasingly better author-agent of his own projects and acts.

\section{FINAL CONSIDERATIONS IN ORDER TO BUILT FIELDS OF EDUCATION: TRIPLE TECHNICAL MEANING OF THE CULTURAL AREA AS A FIELD OF EDUCATION}

From the perspective of the knowledge of education and regarding the formative sense of 'education' we can identify and define, three possible meanings of the cultural areas as an instrument of education in any of its expressions. They give meaning to the cultural areas-education relationship "as education", "as cultural experience" and "as professional and vocational experience", that is, the conceptual difference of cultural area is justified as a field of education, as it is reflected in Chart 6 : 
Chart 6: The triple technical meaning of cultural area as a field of education

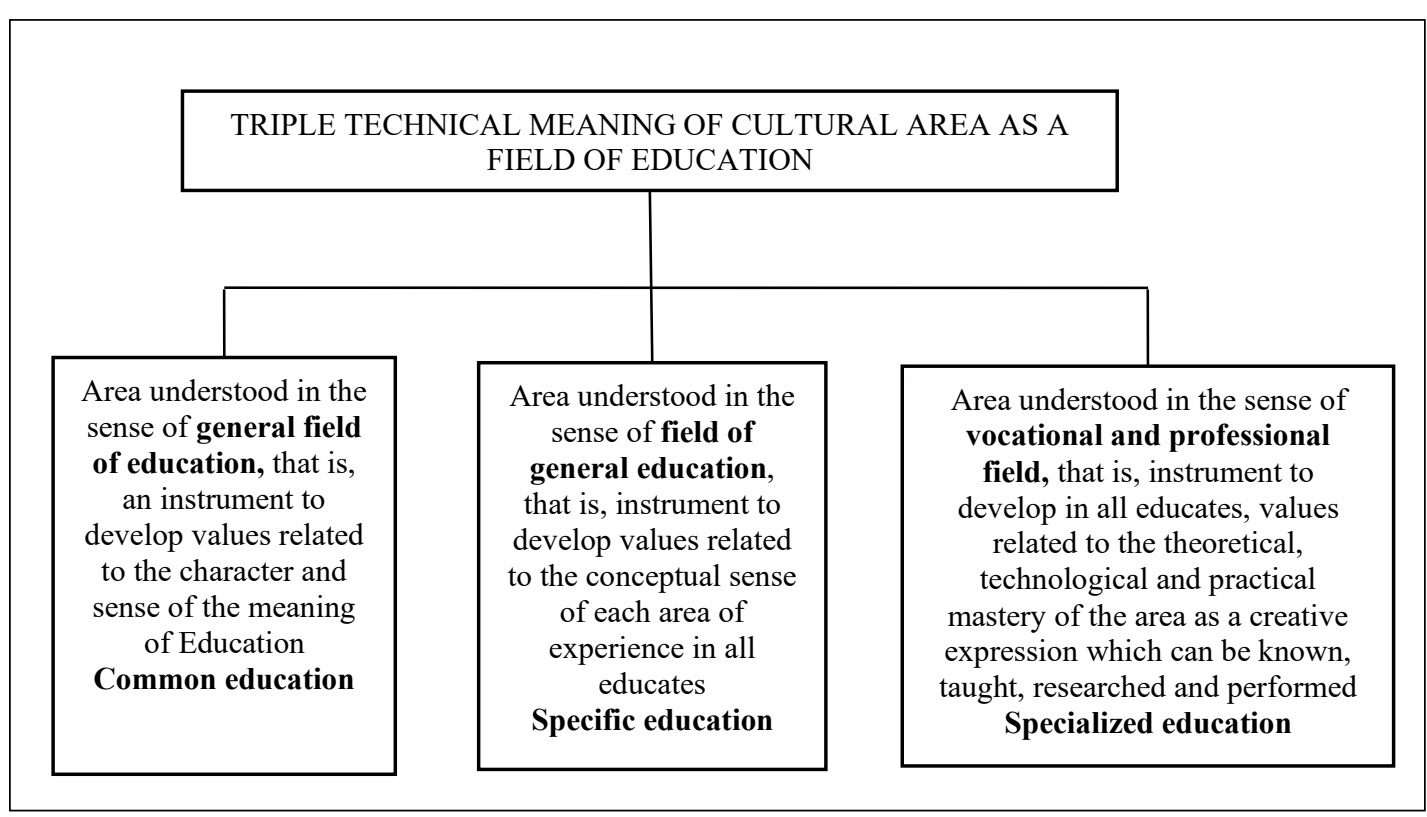

Source: Touriñán, 2014a, p. 659.

In the first two meanings, and by means of the cultural area, we perform the aims of education in general, related to the meaning of "education" and the aims of general education identifiable from the conceptual sense of cultural area. The third meaning covers the sense of education itself from the cultural area as professional and vocational orientation for a certain area. In the first two meanings, we give content to the expression "education through the cultural area". In the third meaning we give content to the expression "education for a cultural area".

For us, the cultural area, seen from the perspective of field of education is not only education "for" a cultural area (vocational development and career), preferably focused on the area as a theoretical knowledge, field of research and creative activity, whose technical mastering and practical execution can be taught. The cultural area is also education "through" the cultural area (general field of education and field of general education). General field of education which permits focusing pedagogical intervention on the cultural area so as to develop the character and sense which is typical of education, -as it should be done with mathematics, language, geography or any basic curricular discipline of general education- and field of general education in which we acquire competences for the use and construction of valuable experience about the conceptual sense of the area, assumable as common heritage for all educates as part of their integral development. We can know a cultural area, we can teach an area and we can educate "with" that cultural area, whether to develop the character and sense inherent in the meaning of education in educatees, to develop the conceptual sense of the area within each educatee's general education; or to contribute to form specialists in the cultural area from a vocational or professional perspective (Touriñán, 2015 y 2019f). 
Thus, we can strictly speak about education "for" a specific cultural area (that of my vocation or my profession), but we can also talk about general education "through" the cultural area. In addition to being a field of vocational training and professional development, education WITH a cultural area is a general field of education, but it is also a field of general education, that is why it can be taught to educatees as common education and as general and basic education.

As a general field of education, education WITH a cultural area fulfils the conditions inherent to general areas of education: it adjusts to values derived from the criteria of meaning of 'education'. For this reason, the three possible meanings of the cultural area as a problem of education should not be mistaken, since they give meaning to the "cultural area-education" relationship as common educational experience, as specific educational experience and as specialised educational experience (Touriñán, 2020c, 2016 y 2019f):

- The cultural area as a general field of education which provide common educational values related to the particular character and sense of education; they are inherent values to the meaning of educating

- The cultural area as a field of general education which provides specific educational values related to the conceptual sense typical of each cultural area used to educate. They are values linked to the meaning of each cultural area: what it is, how it improves my ability to make decisions, how it shapes me, how it helps me build my life project

- The cultural area as a field of professional and vocational development which provides specialised educational values by means of the theoretical, technological and practice knowledge of the cultural area.

These proposals make it possible to identify education better and better: first, as common education (general field of education); secondly, as specific education (field of general education) and thirdly, as specialized education (professional and vocational field).

Pedagogy forms a criterion about the fields of education in the generic sense of understanding each cultural area as education field. This is an objective that is only solved from Pedagogy, because each cultural area has to integrate the character and sense traits that are typical of the meaning of education. For this, the area of cultural experience has to be constructed as a field of education, whether it is a general field of education, a field of general education or a field of vocational and professional education (common, specific and specialized education field). And this is feasible, if we interpret and understand the cultural area from the perspective of the knowledge of education provided by Mesoaxiological Pedagogy, because pedagogy is responsible for assessing each cultural area as education and constructing it as a "field of education" (Touriñán, 2017a y 2017b).

Necessarily, as we already know, Pedagogy is specified as Mesoaxiological Pedagogy, because it is the objective of Pedagogy to transform information into knowledge and knowledge into education, building education fields from different cultural areas. Each cultural area is a cognisable, teachable, researchable and attainable experience area which can become an object and goal of education, by transforming itself into an education field. We are in a position to go from general pedagogy to applied pedagogies, building education fields, making the derived educational design and generating the pertinent pedagogical intervention. 


\section{BIBLIOGRAPHIC REFERENCES}

Arendt, H, (1974). La condición humana. Barcelona: Seix Barral.

Ausubel, D. P. (1982). Psicología educativa. Un punto de vista cognoscitivo. México: Trillas, $4^{\text {a }}$ reimp. (Fecha de edición original, 1968).

Ballester, L. y Colom, A. J. (2017). Epistemologías de la complejidad y educación. Barcelona: Octaedro.

Bateson, G. (1979). Mind and Nature: A Necessary Unity (Advances in Systems Theory, Complexity, and the Human Sciences). New York: Hampton Press.

Berlo, D. K. (1979). Elproceso de la comunicación. Introducción a la teoría y a la práctica. Buenos Aires: El Ateneo, $10^{\mathrm{a}}$ reimp.

Bunge, M. (1975). Teoría y realidad. Barcelona: Ariel, $2^{\mathrm{a}}$ ed.

Carr, D. (2014). Diverse Senses, and Six Conceptions, of Education. Revista española de pedagogía, 72 (258), 219230.

Colbert, J. G. (1969). Método. Gran Enciclopedia Rialp. Madrid: Rialp, pp. 667-669.

Colom, A. J. (2008). Per a una pedagogía del laberint. Palma: Univeristat de les Illes Balears.

Damasio, A. (2010). Y el cerebro creó al hombre. Barcelona: Destino, $2^{\mathrm{a}}$ ed. (Original de 2010).

Dearden, R. F.; Hirst, P. H. y Peters, R. S. (Eds.) (1982). Educación y desarrollo de la razón. Formación del sentido crítico. Madrid: Narcea.
Dewey, J. (1998). Cómo pensamos. Nueva exposición de la relación entre pensamiento reflexivo y proceso educativo. Barcelona: Paidós.

Díaz Barriga, F. (2006). Enseñanza situada. Vínculo entre la escuela y la vida. México: McGrawHill.

Esteve, J. M. (2010). Educar: un compromiso con la memoria. Un libro para educar en libertad. Barcelona: Octaedro.

Ferrater, J. (1979). De la materia a la razón. Madrid: Alianza Universidad.

García Aretio, L.; Ruiz Corbella, M. y García Blanco, M. (2009). Claves para la educación. Actores, agentes y escenarios en la sociedad actual. Madrid: Narcea.

Gervilla, E. (2000). Valores del cuerpo educando. Antropología del cuerpo y educación. Barcelona: Herder.

González Álvarez, A. (1947). El principio fundamental de la Metodología. Revista Española de Pedagogía, 5 (17), 7-23.

González, N.; Moll, L. C. y Amanti, K. (2005). Funds of Knowledge: Theorizing Practices in Households, Communities, and Classrooms. Mahwah, N. J.: Lawrence Erlbaum Associates.

Haidt, J. (2006). La hipótesis de la felicidad. La búsqueda de verdades modernas en la sabiduría antigua. Barcelona: Gedisa.

Ladriére, J. (1977). El reto de la racionalidad. Salamanca: Sígueme.

Lipovetsky, G. (1986). La era del vacío. Ensayo sobre el individualismo contemporáneo. Barcelona: Anagrama. 
Luhman, N. (1983). Fin y racionalidad de los sistemas. Sobre la función de los fines en los sistemas sociales. Madrid: Editora Nacional.

Lyotard, J. F. (1984). La condición postmoderna. Madrid: Cátedra.

Mantovani, J. (1972). La educación y sus tres problemas. Buenos Aires: El Ateneo. $9^{\mathrm{a}}$ ed.

Marina, J. A. (2009). El aprendizaje de la sabiduría. Aprender a vivir/ aprender a convivir. Barcelona: Ariel.

Maslow, A. H. (1982). La amplitud potencial de la naturaleza humana. México: Trillas.

Morin, E. (2009). El método 5. La humanidad de la humanidad. Madrid: Cátedra. $4^{\mathrm{a}} \mathrm{ed}$.

Mosterín, J. (2008). La naturaleza humana. Madrid: Espasa Calpe.

Novak, J. D. (1998). Conocimiento y aprendizaje. Los mapas conceptuales como herramientas facilitadoras para escuelas y empresas. Madrid: Alianza Editorial.

Peters, R. S. (1979). Ethics and education. Londres: G. Allen and Unwin, 1a ed. 7a reimp.

Pinker, S. (2003). La tabla rasa. La negación moderna de la naturaleza humana. Madrid: Paidós.

Pinker, S. (2011). Cómo funciona la mente. Barcelona: Destino. $3^{\mathrm{a}}$ reimp. (Original de 1997).

Polanyi, M. (1978). Personal Knowledge. Towards a Postcritical Philosophy. Londres: Routledge and Kegan Paul. (Fecha $1^{\mathrm{a} e d .}$ 1958).
Prigogine, I. (1997). El fin de las certidumbres. Madrid: Tecnos.

Prigogine, I. y Stengers, I. (1983). La nueva alianza. Metamorfosis de la ciencia. Madrid: Alianza Universidad.

Pring, R. (2014). From Disguised Nonsense to Patent Nonsense: Thinking Philosophically. Revista española de pedagogía, 72 (258), 231-248.

Quintana, J. Ma (1988). Teoría de la Educación. Concepción antinómica de la educación. Madrid: Dykinson.

Reig, D. (2012). Zonas de Desarrollo Próximo, Entornos Personales de Aprendizaje e Internet como Derecho Fundamental. Consultado 27 de febrero de 2013. http://www.dreig.eu/caparazon

Sáez Alonso, R. (2007). La Teoría de la Educación: Una búsqueda sin término en la construcción del conocimiento de la Educación. Encounters on Education, (8), 109-126.

Scheffler, I. (1970). El lenguaje de la educación. Buenos Aires: El Ateneo.

SI(e)TE. Educación (2016). Repensar las ideas dominantes en la educación. Santiago de Compostela: Andavira.

SI(e)TE. Educación (2018). La Pedagogía, hoy. Santiago de Compostela: Andavira.

SI(e)TE. Educación (2020). Saber para hacer en educación. Santiago de Compostela: Andavira.

Sztajn, P.; Confrey, J.; Wilson, P. H. y Edington, C. (2012). Learning Trajectory Based Instruction: Toward a Theory of Teaching. Educational Researcher, 41 (5), 147-156. 
Touriñán, J. M. (2013a). Conocer, enseñar y educar no significan lo mismo. El carácter y el sentido de la educación como referentes de su significado desde la mirada pedagógica. Teoría de la educación. Revista interuniversitaria, 25 (1), 25-46.

Touriñán, J. M. (2013b). ¿Enseñar áreas culturales o educar con las áreas culturales?, en SI(e)TE (2013). Desmitificación y crítica de la educación actual. Barcelona: Octaedro, pp. 5792.

Touriñán, J. M. (2014a). Dónde está la educación. Actividad común interna y elementos estructurales de la intervención. A Coruña: Netbiblo.

Touriñán, J. M. (2014b) Dónde está la educación. Definir retos y comprender estrategias A propósito de un libro de 2014. REINED, 12 (1), 6-31.

Touriñán, J. M. (2014c). Conocer, enseñar y educar no son lo mismo desde la mirada pedagógica. El reto de la construcción de ámbitos de educación. Boletín REDIPE, 3 (3), febrero, 6-30.

Touriñán, J.M.(2015).Pedagogíamesoaxiológica y concepto de educación. Santiago de Compostela: Andavira. $2^{a}$ edición disponible de 2016.

Touriñán, J. M. (2016). Pedagogía general. Principios de educación y principios de intervención. A Coruña: Bello y Martínez.

Touriñán, J. M. (2017a). Mentalidad pedagógica y diseño educativo. De la pedagogía general a las pedagogías aplicadas en la función de educar. Santiago de Compostela: Andavira.
Touriñán, J. M. (2017b). El concepto de educación: carácter, sentido pedagógico, significado y orientación formativa temporal. Hacia la construcción de ámbitos de educación. Revista Boletín Redipe, 6 (12), diciembre, 24-65.

Touriñán, J. M. (2018). Concepto de educación y conocimiento de la educación. The Concept of Education and the Knowledge of Education. ColombiaNueva York: Redipe (Bowker-Books).

Touriñán, J. M. (2019a). Estudiar es actividad común externa y siempre educamos con la actividad. Una aproximación desde la perspectiva mesoaxiológica. Teoría de la Educación. Revista interuniversitaria, 31 (2), 7-39.

Touriñán, J. M. (2019b). La relación educativa es un concepto con significado propio que requiere concordancia entre valores y sentimientos en cada interacción. Sophia, colección de Filosofía de la Educación, 26 (1), 223-279.

Touriñán, J. M. (2019c). Imagen social de la Pedagogía. Competencia técnica y educación de calidad, en C. Naval, J. Vergara, A. Rodríguez y A. Bernal (Coords.), Reflexiones teóricas sobre la educación. Madrid; Dykinson, pp. 145192.

Touriñán, J. M. (2019d). ¿Qué estamos haciendo mal? Una reflexión desde la Pedagogía, en $\mathrm{A}$. de la Herrán, J. M. Valle y J. L. Villena (Coords.), ¿Qué estamos haciendo mal en la educación? Reflexiones pedagógicas para la investigación, la enseñanza y la formación. Barcelona: Octaedro, pp. 287-330. 
Touriñán, J. M. (2019e). Pedagogía, profesión, conocimiento y educación: una aproximación mesoaxiológica a la relación desde la disciplina, la carrera y la función de educar. Tendencias Pedagógicas, (34), 93-115.

Touriñán, J. M. (2019f). Valores educativos comunes y específicos: análisis descriptivo de su integración pedagógica en las materias escolares a partir de la percepción de los docentes sobre su actividad. Revista Boletín Redipe, 8 (6), junio, 23-49.

Touriñán, J. M. (2020a). Pedagogía, competencia técnica y transferencia de conocimiento. La perspectiva mesoaxiológica de la Pedagogía. Santiago de Compostela: Andvira.

Touriñán, J. M. (2020b). Los medios y su valor pedagógico en la relación educativa, en A. Medina, A. de la Herrán y $\mathrm{M}^{\mathrm{a}}$ C. Domínguez, Hacia una Didáctica humanista. Colombia-Madrid: Redipe (Bowker Books in print)-UNED, pp. 199268.

Touriñán, J. M. (2020c). Pedagogía de las artes. La perspectiva mesoaxiológica. Santiago de Compostela: Andavira.

Touriñán, J. M. (Dir.) (2012). Desarrollo cívico, sentido intercultural de la educación y convivencia cualificada y especificada. Coruña: Netbiblo.

Touriñán, J. M. y Longueira, S. (Coords.) (2018). La construcción de ámbitos de educación. Pedagogía general y aplicada. Santiago de Compostela: Andavira.

Touriñán, J. M. y Sáez, R. (2006). La metodología de investigación y la construcción del conocimiento de la educación. Revista galega do ensino, $2^{\mathrm{a}}$ época, 14 (48), 89-130 y $377-410$.

Touriñán, J. M. y Sáez, R. (2012). Teoría de la educación, metodología y focalizaciones. La mirada pedagógica. A Coruña: Netbiblo. Hay edición actualizada en Touriñán, J. M. y Sáez, R. (2015). La mirada pedagógica. Teoría de la educación, metodología y focalizaciones. Santiago de Compostela: Andavira.

Zubiri, X. (1978). Naturaleza, Historia, Dios. Madrid: Editora Nacional, $7^{\mathrm{a}}$ ed.

Zubiri, X. (2006). Tres dimensiones del ser humano: individual, social, histórica. Madrid: Alianza Editorial. Fundación Xabier Zubiri. 